\title{
STUDIES ON MARINE GAMMARIDEAN AMPHIPODA OF THE SETO INLAND SEA. III
}

$\operatorname{AUTHOR}(S):$

Nagata, Kizo

\section{CITATION:}

Nagata, Kizo. STUDIES ON MARINE GAMMARIDEAN AMPHIPODA OF THE SETO INLAND SEA. III. PUBLICATIONS OF THE SETO MARINE BIOLOGICAL LABORATORY 1965, 13(4): 291326

ISSUE DATE:

1965-12-15

URL:

http://hdl.handle.net/2433/175410

RIGHT: 


\title{
STUDIES ON MARINE GAMMARIDEAN AMPHIPODA OF THE SETO INLAND SEA. III
}

\author{
KIZOO NAGATA \\ Inland Sea Regional Fisheries Research Laboratory, Hiroshima
}

With 18 Text-figures

\section{CONTENTS}

PART I Systematic Account (continued). Systematics (with Figs. 27-43)

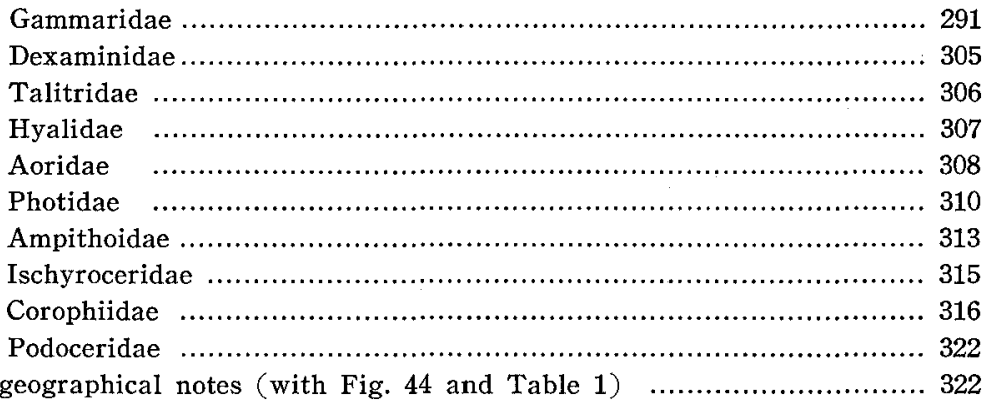

\section{Family GAMMARIDAE \\ Key to the species of Gammaridae}

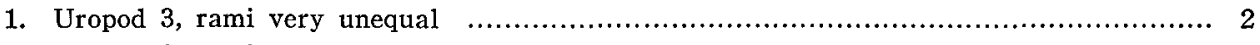

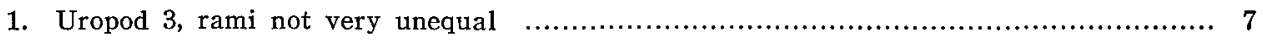

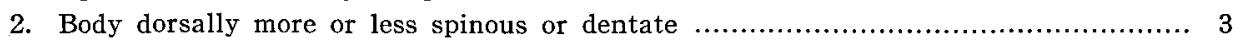

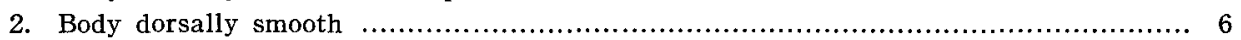

3. Body with groups of dorsal spinules on all of pleon segments

Anisogammarus (E.) annandalei

3. Body without groups of dorsal spinules on all of pleon segments

4. Body without a median dorsal tooth on all of pleon segments

4. Body with a median dorsal tooth on some of pleon segments

Melita koreana

5. Pleon segments 1-4 each with a median dorsal tooth, flanked with some minute teeth on either side Melita denticulata

5. Pleon segments 1-3 each with only a median dorsal tooth ................ Melita tuberculata

5. Pleon segments 2-4 each with only a median dorsal tooth Melita japonica

6. Gnathopods $1-2$, article 6 similar in shape Eriopisella sechellensis

6. Gnathopods $1-2$, article 6 dissimilar in shape Eriopisa elongata

Publ. Seto Mar, Biol. Lab., XIII (4), 291-326, 1965. (Article 16) 
7. Body dorsally quite smooth Maera serratipalma

7. Body dorsally more or less dentate Megaluropus agilis

8. Uropod 3, rami oblong oval, rounded at apex

8. Uropod 3, rami not oval, not rounded at apex Ceradocus (D.) capensis

9. Third pleonal epimeron with hind margin serrate Maerella tenuimana

9. Third pleonal epimeron with hind margin not serrate

\section{Anisogammarus (Eogammarus) annandalei (TATTERSALL)}

Gammarus annandalei TAtTersall 1922, p. 445, pl. 20, figs. 1-18; Ueno 1933, p. 111 ; Ueno 1935, p. $90,92$.

Anisogammarus (E.) annandalei, SChellenterg 1937, p. 274 ; Stephensen 1944, p. 52, fig. 13.

Material examined: Areas IV (2 at St. 14, see NaGata 1960, fig. 2), V (1), IX $\mathrm{d}$ (1); up to ca. $20 \mathrm{~mm}$ long; in Areas IV and V, from a depth of $2 \mathrm{~m}$ in high water at the mouth of river; in Area IX-d, from the surface water at night, $2-3 \mathrm{~m}$ in depth in high water.

Distribution: Known only from fresh water in the past records ; Southern Kuril Is., Southern Sachalin, Japan (Hokkaidô to Lake Biwa), and China (Eastern China and Yunnan). Here, the first record from brackish waters, the mouth of river (it is noted that the species is found from the surface water in high water of Area IX-d, which is not just near the mouth of river but there is only a little inflow of the drainage).

\section{Melita koreana STEPHENSEN}

Melita koreana STEPHENSEN 1944, p. 39, figs. 6.8.

Melita rylovae Bulycheva 1955, p. 201, fig. 5.

? Melita coroninii, Stebbing 1906, p. 424 ; Chevreux \& FAGE 1925, p. 229, figs. 238, 240.

Material examined: Areas I (2), V (30), TI (13), VII (17), IX-a (18), IX-b (1), IX-d (8), XII (3), XIV (11). Total: 103 specimens, up to $12.7 \mathrm{~mm}$ in length; from intertidal to a depth of $1.5 \mathrm{~m}$ in low-water.

Remarks: The specimens somewhat differ from STEPHENSEn's description and figures in the following respects: Pleon segment 5 is armed with a laterodorsal tooth and 2-3 spines on each side. The teeth are much minute in comparatively small specimens, and are often apt to be overlooked (STEPHENSEN must have lost sight of this fact). This dorsal armature of my specimens agrees with that of $M$. coroninii HELler from the coast of Mediterranean.

The lower posterior corner of this third pleonal epimeron entirely agrees with that of $M$. coroninii figured by Chevreux \& FAge. The corner appears to be somewhat variable in shape, and to be of no specific value. The subrectangular form of the corner described by STEPHENSEN is sometimes also seen in my collections, 
Male gnathopod 1, particularly in the distal end of the legs, agrees well with Chevreux \& Fage's description and figure for $M$. coroninii. The finger figured by STEPHENSEN is probably not actually the true one but it is the recurved antero-distal process of article 6, and the genuine finger is folding down on the inner side of the palm. Such a false appearance as figured by STEPhensen is also often seen in the present specimens. Therefore, J. L. BARNARD's key by which $M$. koreana is separated from $M$. coroninii should be revised (J. L. BARNARD 1962a, p. 108).

Otherwise, My specimens quite agree with Stephensen's one. Melita koreana is known by STEPHENSEN from Makinoshima, Fuzan, Korea, and my specimens referred to this species are also found by me from the west coast of Kyûshû. Therefore, it is almost incredible that the present specimens are wholly distinctive from $M$. koreana Stephensen. On the other hand, as seen in the above-mentioned consideration, my specimens much resemble $M$. coroninii HELLER, and it seems to me that $M$. koreana may be a synonym of $M$. coroninii. As a matter of fact, I am now unable to distinguish the former from the latter, except for female coxa 6 . In the former, female coxa 6 has the front lobe produced to a recurved process, while in the latter the hooked process of coxa 6 has been described neither in STEBbing's monograph (1906, 1. c.) nor in ChEvREux \& FAGE's one (1925, 1. c.), although it was unable to refer to HelleR's original description (1886). It is now necessary to confirm whether $M$. coroninii is actually armed with the hooked process on female coxa 6 .

I believe that Melita rylovae Bulycheva from the Russian coast of Japan Sea is a synonym of $M$. koreana. The former is only a fully grown-up form of the latter. Dorsal armature on pleon segment 5 as mentioned above is quite conformable between $M$. rylovae and my specimens, and the presence of one pair of subdorsal tooth on pleon segments 2 and 3 begins to appear in about $9-10 \mathrm{~mm}$ long specimens in the Seto Inland Sea, and in much fully grown-up my specimens the teeth are also developed on pleon segment 1 . An evidence of the continuity between koreana-form and rylovae-form may be proved by many facts that the both forms occurred together in a collection at a certain station, and in fact I can find no other qualitative differences between $M$. rylovae and my specimens of $M$. koreana, particularly in characteristic features of male gnathopods 1 and 2 , and the hooked process of female coxa 6 .

Distribution: Korea (Makinoshima) and Bay of the Great Peter.

Melita denticulata, sp. nov.

(Fig. 27)

Material examined: Areas IV (7), VII (3); up to $4.5 \mathrm{~mm}$ in length, from 
depths of $1-2 \mathrm{~m}$ in low-water.

Description: Pleon segments 1-4 each with a large medio-dorsal tooth, flanked with some minute teeth on each side; pleon segment 5 with a laterodorsal tooth on each side, together with a spine at the same base; pleon

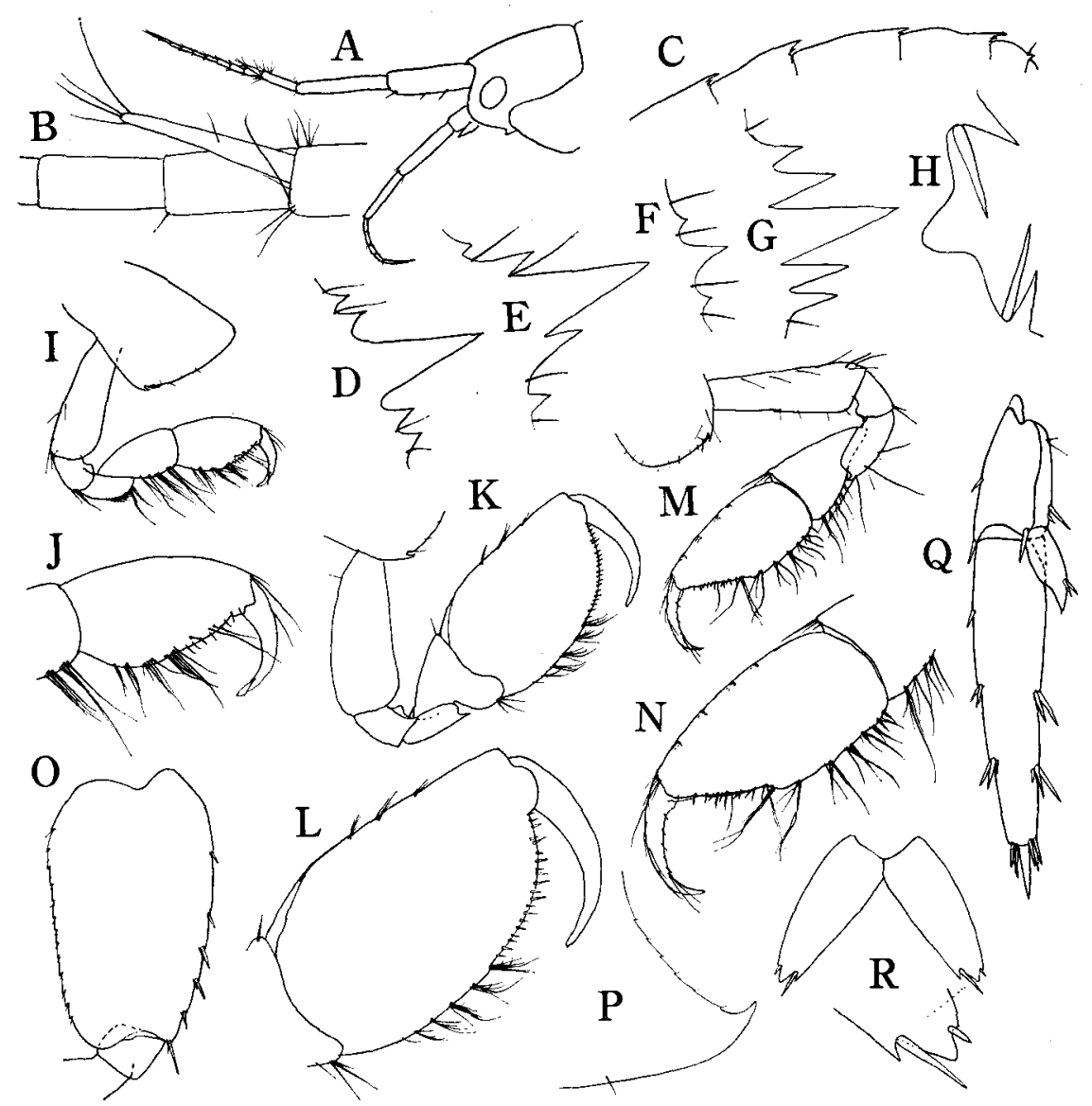

Fig. 27. Melita denticulata, sp. nov. Male, $4.0 \mathrm{~mm}$ : A, head and antennae; B, accessory flagellum of antenna 1 ; C, dorsal profile of pleon segments $1-5 ; \mathrm{D}, \mathrm{E}, \mathrm{F}$, $\mathrm{G}, \mathrm{H}$, upper view of dorsal teeth of pleon segments $1,2,3,4,5 ; \mathrm{P}$. lower hind corner of third pleonal epimeron; $Q$, uropod 3. Male, holotype, $4.0 \mathrm{~mm}: 1$, J, gnathopod 1 and the end magnified; K, L, gnathopod 2 and the end magnified; $\mathrm{O}$, article 2 of peraeopod 4 , right. Female, ovig., $4.5 \mathrm{~mm}: \mathrm{M}, \mathrm{N}$, gnathopod 2 and the end magnified; $\mathrm{R}$, telson.

segment 6 lacks any tooth. Coxa 1 distally expanded, coxae 1-3 each with a small acute tooth at the lower hind corner. The third pleonal epimeron with the posterior corner produced into an acute upturned tooth, minutely serrated above. Antennae comparatively short; antenna 1 much shorter than a half 
the length of the body; peduncular article 2 of antenna 1 equal in length to article 1 ; flagellum of antenna 1 shorter than the peduncle, 9-10 jointed; accessory flagellum somewhat long, 1-jointed ; flagellum of antenna 2 with 5-6 joints. Gnathopod 1 like figured here, similar in both sexes. Gnathopod 2, in male, article 2 stout, article 6 broad and tumid, the palm evenly rounded extending over the end of the hind margin, undefined by any process, and lined with a row of short spines, the hind margin with some groups of setae, finger smooth, not acute at apex; in female, article 2 normal, article 5 relatively longer, article 6 subtrapezoid the palm obliquely straight, undefined by any distinct tooth. Telson simply armed as figured here, each lobe not acute at apex, with one short spine outside the apex, one long spine inside. Otherwise, the new species nearly like in SARS' figures for $M$. dentata (SARS 1896, pl. 181, fig. 1).

Holotype: KN No. 2925, male, $4.0 \mathrm{~mm}$. Type locality: St. 2 in Area VII, $4 \mathrm{~m}$ in high-water, Jan. 23,1957 , mud. Zostera belt, W. T. $9.8^{\circ} \mathrm{C}$ (bottom), Cl. $18.16 \%$ (bottom).

Remarks: The new species is closely related to $M$. dentata (KR $\phi \mathrm{YER}$ ) (1.c.) in general appearance; the latter species has been recorded from Japan (? Japan Sea), according to Stephensen (1940a, p. 309). IwASA has also inserted the species as found near low-water marks into "Illustrated encyclopedia of the fauna of Japan" (press of 1957). The specimens at my hand are all up to $4.5 \mathrm{~mm}$ in length. At least, I suspected that the present specimens might be a juvenile form having a link with such an adult form as figured by SARs. However, one female specimen at hand is already ovigerous at $4.5 \mathrm{~mm}$ long, and I can not, in the present stage of my work, believe the specimens to be identical with $M$. dentata by the following characters; that is, by having a prominent median dorsal tooth on each of pleon segments $1-4$, by lacking a medial dorsal tooth on pleon segment 5 , by having no armature on pleon segment 6 , by having a serration on the posterior edge of the third pleonal epimeron, by having a comparatively short antennae, by being not produced to an acute tooth at the postantennal corner of head, by having distally expanded coxa 1, and by the form of male gnathopod 2.

The new species marvelously resembles $M$. lagunae Olvieira from Rio de Janeiro (1953, p. 316, figs. 5-6) in male gnathopod 2, but differs from the latter by the dorsal appearance, and the structure of gnathopod 1 .

\section{Melita tuberculata, sp. nov.}

(Figs. 28-29)

Material examined: Areas VII (1), X (1), XI-a (15); up to $9.0 \mathrm{~mm}$ in length ; from depths of $7.5-56.0 \mathrm{~m}$. 
Description of male, $8.0 \mathrm{~mm}$ long: Body slender, pleon segment 1,2 , and 3 each with a medial dorsal tooth, pleon segment 5 with two small laterodorsal teeth enclosing a spine on each side, pleon segments 4 and 6 having no dorsal armature. Coxa 1 expanded distally; the third pleonal epimeron with the hind lower corner produced to a short upturned tooth, slightly serrate below, and the hind edge bearing a long seta above the corner. Eyes dark, rounded oval, post-antennal corner distinct but not acute. Antenna 1 reaching nearly the end of pleon segment 3 ; peduncular article 2 about 1.5 times as long as article 1 ; article 3 shorter than one half the length of article 1 ; flagellum 29-jointed; accessory flagellum with 4 joints plus 1 rudimentary one. Antenna

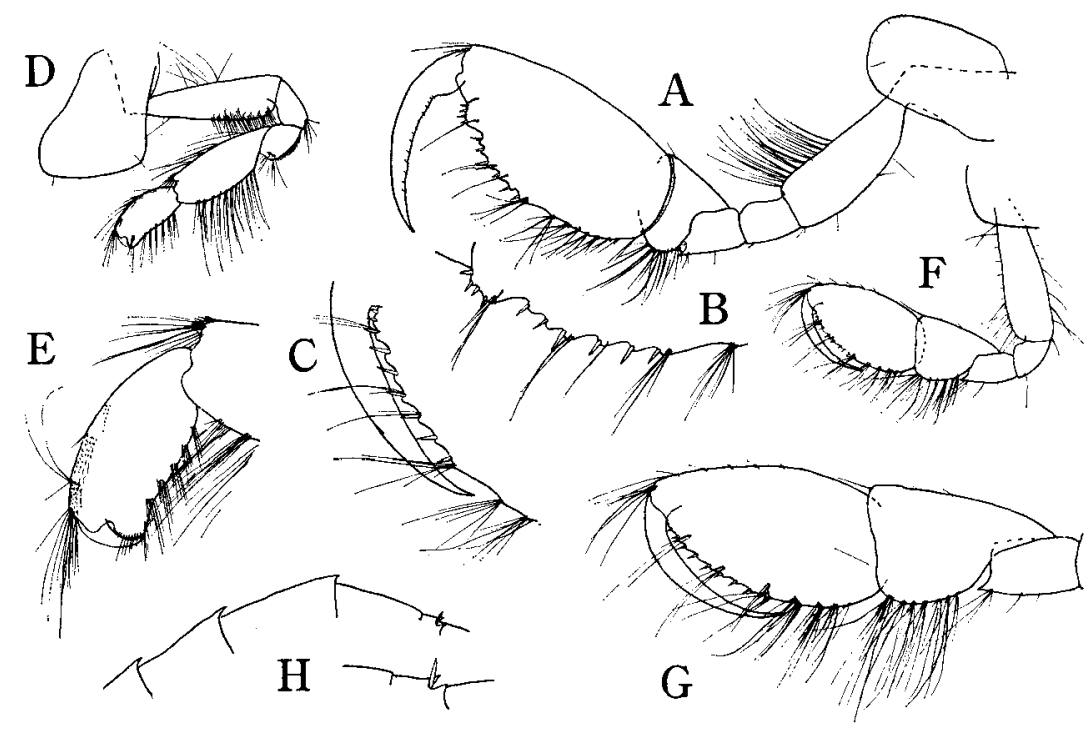

Fig. 28. Melita tuberculata, sp. nov. Male, holotype, $9.0 \mathrm{~mm}$ : A, B, gnathopod 2 and the palm enlarged; D, gnathopod 1 . Female, ovig., $6.1 \mathrm{~mm} ; \mathrm{F}, \mathrm{G}$, gnathopod 2 and its articles 4-7 magnified; $\mathrm{H}$, dorsal profile of pleon segments 1-5, with the segment 5 magnified. Male, $6.4 \mathrm{~mm}: \mathrm{C}$, palm of gnathopod 2; E, end of gnathopod 1.

2 reaching slightly beyond the middle of flagellum of antenna 1 ; peduncular article 5 slightly shorter than article 4, somewhat narrower; flagellum a little shorter than article 5, with 11 joints. Gnathopod 1, anterior margin of article 2 with a continuous groove through the length, distally densely setose; article 5 much longer than article 6 , bearing a small bump covered with many bristles (?) at the antero-distal corner; article 6 proximally somewhat narrow, the palm transverse, short, and slightly convex, lined with 9 setae on the posterior half; finger short, abruptly narrowing to the apex. Gnathopod 2 much larger than gnathopod 1 ; article 2 with the anterior margin like in 
gnathopod 1 ; article 5 produced to an acute small tooth at the postero-distal corner; article 6 very large, fully elongate, the palm very oblique, lined with several tubercles, each with a short spine, except for the one near the finger hinge which is larger, bearing 3-4 spines, undefined by a distinct angle;

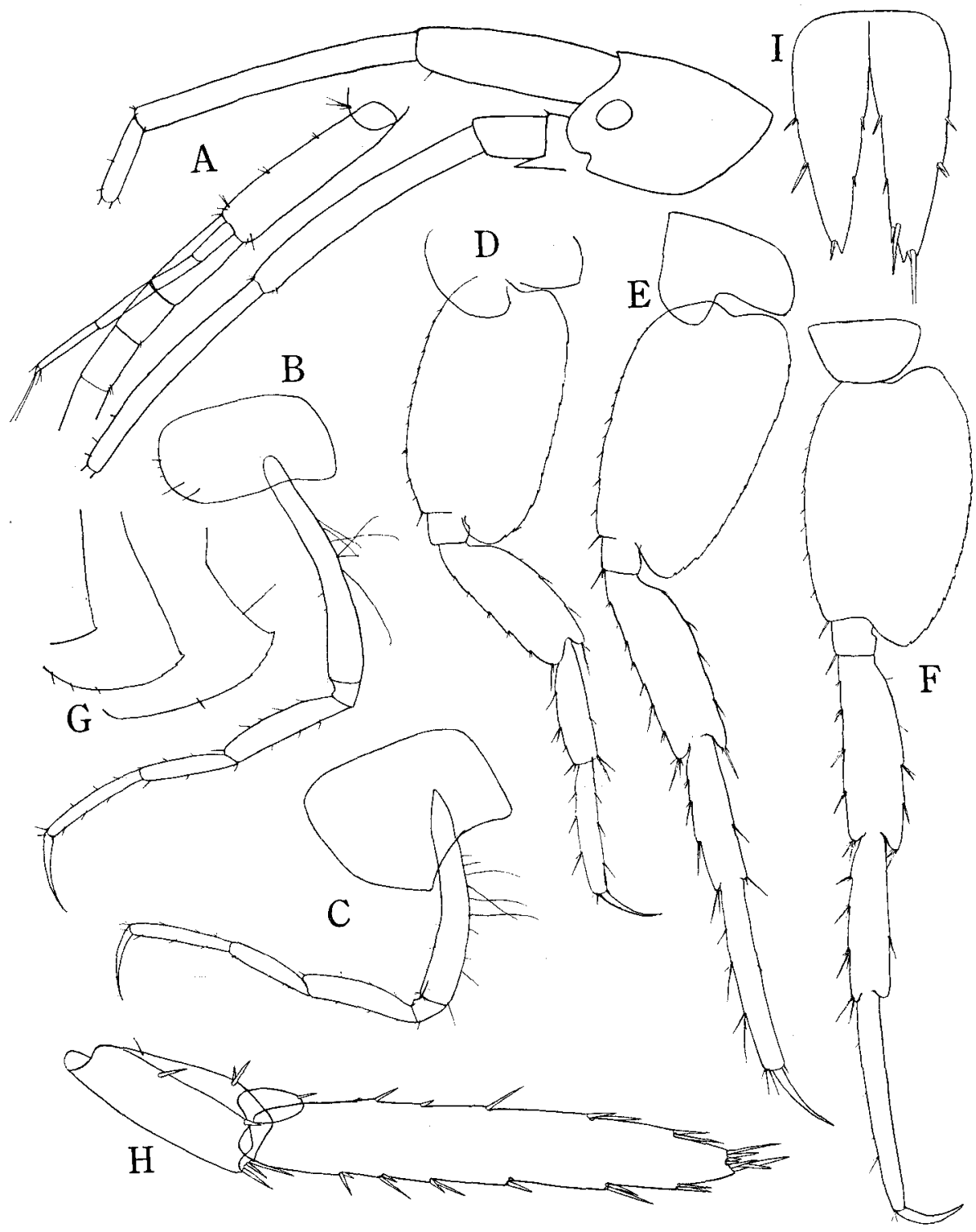

Fig. 29. Melita tuberculata, sp. nov. Male, $8 \mathrm{~mm}: \mathrm{A}$, head and peduncle of antennae, with accessory flagellum magnified; B, C, D, E, F, peraeopods $1,2,3,4,5$; G, lower posterior corner of pleonal epimera $1-3 ; \mathrm{H}$, uropod $3 ; \mathrm{I}$, telson. 
finger somewhat longer than palm, acute at apex. Gnathopods 1-2 rather more setiferous than in the preceding species. Peraeopods 1 and 2 slender and delicate, finger relatively long, about two thirds as long as article 6 . Peraeopods 3-5, article 2 broadly oval, minutely serrate along the hind margin, with the lower hind corner somewhat produced downwards, rounded; peraeopods 4 and 5 nearly equal in length. Uropod 3 much elongate, outer ramus more than twice as long as the peduncle, the apex rather truncate, with 6-7 unequal spines, inner ramus not twice as long as broad. Telson about 1.5 times as long as broad, cleft nearly to the base, each lobe rather narrow, the apices with a small point, both margin of each lobe armed with 2-3 small bundles of spine respectively. Color pale brown.

Female differs from male in gnathopod 2; gnathopod 2 in female larger than gnathopod 1 , but not so larger as male, article 5 relatively long, article 6 with the palm not prominently tuberculated, more oblique, and evenly running into the hind margin.

Holotype: KN No. 2921, male, $9.0 \mathrm{~mm}$. Type locality: St. 7 in Area XI-a, 47-51 m, June 13, 1959, sandy mud.

Remarks: The new species has no agreement with any species shown in "pleonal tooth formulas of species in genus Melita" by J.L. BARNARD (1962a, p. 107), and is easily distinguished from any other species by the dorsal appearance, gnathopods 1-2, pleonal epimera, and telson.

\section{Melita japonica, sp. nov.}

(Fig. 30)

Material examined: Area VII, one male $(8.0 \mathrm{~mm})$ and one female $(7.0 \mathrm{~mm})$ specimens. Depth : $2.5-3.0 \mathrm{~m}$ in high water; near the low tide marks.

Description: Pleon segments 2, 3, and 4 each with a large medio-dorsal tooth, pleon segment 5 with two small subdorsal teeth enclosing a spine on each side, pleon segments 1 and 6 without dorsal armature. Coxa 1 scarcely expanded distally. Eyes rounded oval. Antenna 1, article 3 of peduncle much longer in comparison with that of $M$. desdichada J. L. BARNARD (1962a, p. 110, fig. 22), about a half the length of article 1 , accessory flagellum with $3-5$ joints. Gnathopod 1 in male, article 6 oblong oval, slightly longer than article 5, palm evenly rounded, lined with spinules, undefined from the hind margin; the hind margin of articles 4 and 6 covered with a thick brush of short bristles, and also the antero-distal corner of article 5 armed with some serrate spinelike setae broadened at the base and a small bump covered with many small bristles; finger sharply curved at the base. Gnathopod 1 in female, article 6 rather roundly oval, slightly shorter than article 5 ; finger normal, somewhat shorter; otherwise nearly like in male. Gnathopod 2 in male, article 4 
with the postero-distal corner produced to a small acute tooth, article 5 short, cup-shaped, article 6 large, ovate, narrowed distally, palm obliquely rounded, slightly crenulate, lined with short spines, undefined from and running into the hind margin, finger slightly longer than palm; in female, article 5 relatively longer, article 6 with the palm obliquely truncated, undefined by any distinct process from the hind margin, and armed with two short spines and

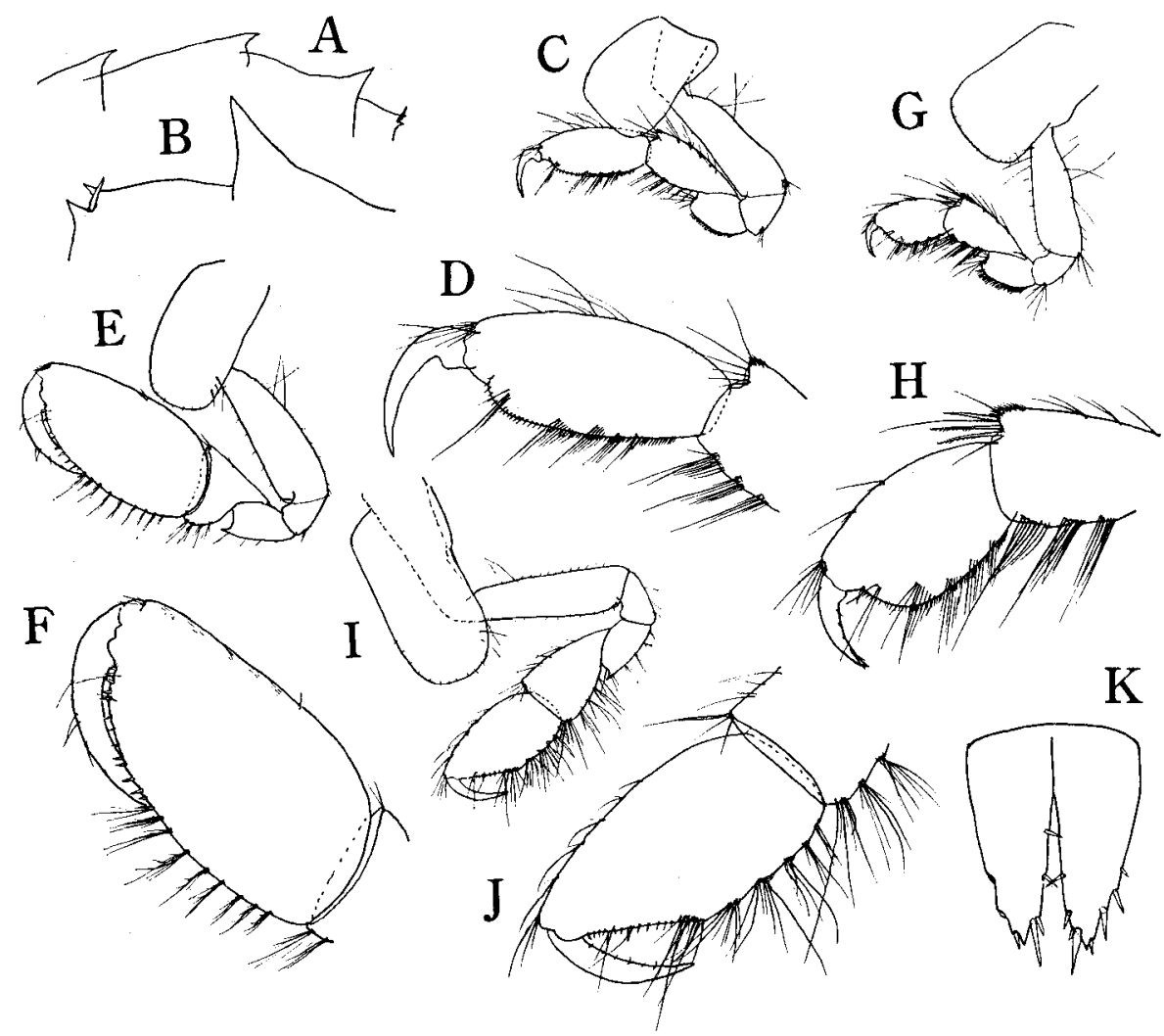

Fig. 30. Melita japonica, sp. nov. Male, holotype $8 \mathrm{~mm}$ : A, B, dorsal profile of pleon segments 2-5, and the segments 4-5 magnified; C, D, gnathopod 1 , and the articles 5-7 magnified; E, F, gnathopod 2, and the end magnified; $\mathrm{K}$, telson. Female, $7 \mathrm{~mm}$ : G, H, gnathopod 1, and the articles 5-7 enlarged; I, J, gnathopod 2, and the end magnified.

many spinules. Pleonal epimera, peraeopods, uropods, telson, and other respects are all nearly like in $M$. desdichada (1. c.).

Holotype: KN No. 3170, male, $8.0 \mathrm{~mm}$. Type locality: St. 7 in Area VII, near low water marks, sand, W.T. about $10^{\circ} \mathrm{C}$ in high water (bottom), Cl. $18.16 \%$, Jan. 23, 1957. 
Remarks: The new species is fairly well relaled to $M$. desdichada, but distinguished by the dorsal appearance, and somewhat different forms of gnathopods 1 and 2 . The new one is also closely related to $M$. californica Alderman (1936, p. 60, figs. 26-32) particularly in gnathopods 1-2, and the proportional length of peduncular article 3 of antenna 1 , but here distinguished by the following respects; in $M$. californica, pleon segments $2-3$ untoothed, pleon segment 4 with three dorsal teeth, eyes rounded, male coxa 1 distally expanded, article 5 of male gnathopod 1 longer than article 6, palm of article 6 of gnathopod 1 oblique (probably like in J. L. BARNARD's figure of $M$. desdi chada), and article 6 of gnathopod 2 in my specimens more fully elongate. However, the above-mentioned two eastern Pacific species and the present new one appear to be essentially pretty akin to each other. It is also noted that this new one is somewhat related to M. somovae Bulycheva (1952, p. 226, fig. 25).

According to the pleonal tooth formulas of species in the genus Melita given by J. L. BARNARD (1962a, p. 107), the new species agrees with M. lignophila J. L. BARNARD (1961, p. 225, fig. 77) from Gulf of Panama, $915 \mathrm{~m}$ in depth, in the same arrangement of dorsal teeth, i. e. $0,1,1,1,4$ in accordance with the order of pleon segments $1-5$, but in the latter species, eyes absent, and male gnathopod 2 shows a different form in article 6 .

\section{Maera serratipalma, sp. nov.}

(Fig. 31)

Material examined: Areas IV (7), V (1), VI (7), VII (5), IX-b (7), IX-d (14), XI-a (4), XI-b (2), XIII-b (8). Total: 55 specimens, up to $8.0 \mathrm{~mm}$ in length; from near low water marks to $52 \mathrm{~m}$ in depth.

Description: Body slender, smooth; coxae 1-4 shallow, subsquare, the front corner of coxa 1 acutely produced, coxa 5 deeper than coxa 4. Third pleonal epimeron with the lower hind corner produced to an acute small tooth, not serrate. Lateral lobes of head subtruncate, post-antennal corner acutely produced, eyes ovate. Antennae slender; peduncular article 2 of antenna 1 subequal in length to article 1 which bears three spines along the under edge, narrower; flagellum rather shorter than the peduncle, about 17 jointed; accessory flagellum well developed, usually just a little shorter than a half the length of the primary flagellum, about 6 -jointed; antenna 2, glandcone of peduncular article 2 reaching only to the middle of the article 3 , article 5 shorter and narrower than article 4, flagellum subequal in length to peduncular article 5, about 7 -jointed. Maxilla 1, inner plate with 2 setae; mandibular palp nearly typical. Gnathopod 1 ; article 5 as long as article 6, both widened distally, article 5 with the anterior margin very slightly 
depressed near the distal corner. Gnathopod 2 ; article 2 without antero-distal lobe, article 4 produced to an acute postero-distal tooth, article 5 cup-shaped, article 6 very large, longer than broad, nearly rectangular, a little widened to the palm, which is transverse, serrated with 6 subacute denticles, defined by a strong tooth from the hind margin; finger slightly convex at the middle of inner edge.

Peraeopods 1-5; finger each produced to a nail dorsally bearing two minute teeth as figured here. Peraeopods 1 and 2 slender. Peraeopods 3-5;

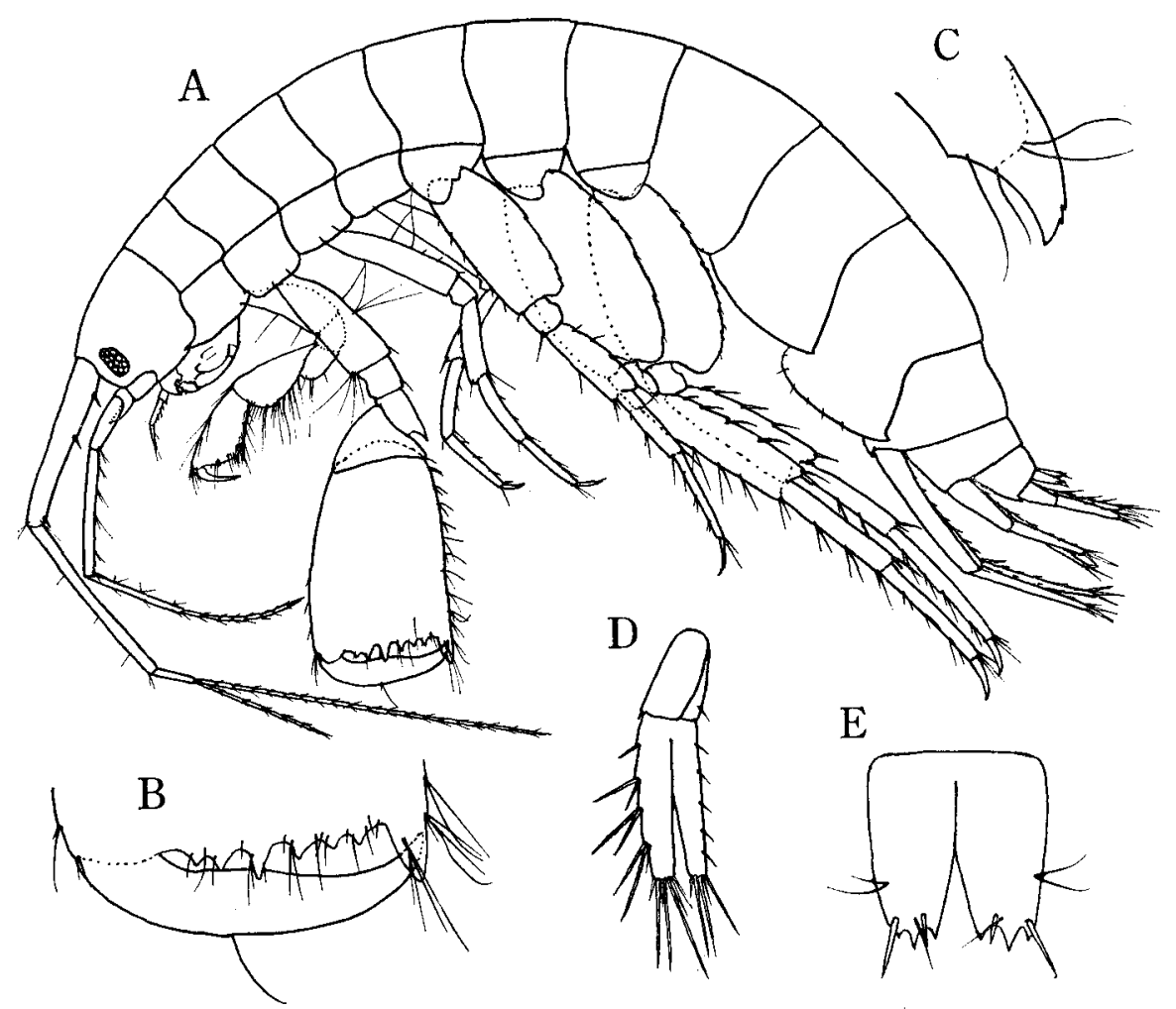

Fig. 31. Maera serratipalma, sp. nov. Male holotype, $7.0 \mathrm{~mm}$ : A, lateral view ; B, end of gnathopod $2 ; \mathrm{C}$, nail of finger of peraeopod $5 ; \mathrm{D}$, uropod $3 ; \mathrm{E}$, telson.

article 2 with the hind margin minutely serrate, article 4 rather broad; article 2 of peraeopod 3 somewhat narrow, while those of peraeopods 4 and 5 moderately expanded; peraeopod 3 much shorter than peraeopods 4 and 5 which are subequal in length. Uropod 3 scarcely extending beyond the other uropods, rami equal or subequal in length, the apices truncate, armed with several unequal spines. Telson slightly longer than broad, deeply cleft, each lobe tridentate at the apex which is armed with a long and a short spine. 
Holotype: $\mathrm{KN}$ No. 3055, male, $7 \mathrm{~mm}$ (figured). Type locality: St. 2 in Area VII, $4.0 \mathrm{~m}$ in high water, Jan. 23,1957 , Zostera belt, mud, W. T. $9.8^{\circ} \mathrm{C}, \mathrm{Cl} .18 .16 \%$.

Remarks: The new species is closely related to $M$. inaequipes (Costa), $M$. quadrimana (DANA), and $M$. pacifica SchellenberG, but distinguished from any of the above three species by a prominent sculpture of the palm of male gnathopod 2, a character unique among the hitherto known species of this genus, and which is consistently represented through the growth series up to $8.2 \mathrm{~mm}$ long in the materials at hand. In the specimens, female could not be distinguished from male by any prominent characters, particularly in gnathopod 2, both sexes show similar form both in the shape and in the size. In fact, this peculiarity is also indicated by WALKER on M. scissimana (1904, p. 273) that the size and shape of the hand of the second gnathopod is much the same in male and female.

\section{Maerella tenuimana (BATE)}

Maera tenuimana, SteBbiNg 1906, p. 436.

Maerella tenuimana, CHevreux 1911, p. 219, fig. 11 \& pl. 15, figs. 1-13; Chevreux \& FAGE 1925 , p. 242 , figs. $253-254$.

Material eqamined: Area XI-b, 2 ovig. female specimens, 4.2 and $4.5 \mathrm{~mm}$ in length; from depths of 50-52 m, Sept. 4, 1960.

Remarks: The present female specimens agree fairly well wilh CHEvREux's description and figures of M. tenuimana, except for the following minor details : The third article of mandibular palp is not fully falcate; dorsal armatures of pleon segments $1-6$ shown by the arrangement of $1,3,3,2,2,0$ in order ; uropod 3 with the rami rather broader than those of female figured by him.

Distribution: Coasts of Scotland, England, and France; Mediterranean (N. of Tunisia), $10-180 \mathrm{~m}$.

\section{Ceradocus (Denticeradocus) capensis SHEARD}

(Fig. 32)

Maera rubromaculatus, STEBBING 1888, p. 1008 (part), pl. 95, E.

Ceradocus (D.) capensis SHEARD 1939, p. 290.

Material examined: Area XI-a, St. 8, 5 specimens, up to $12.5 \mathrm{~mm}$ long; from depths of $47-53 \mathrm{~m}$, sandy mud.

Remarks: SHEARD in his paper of 1939 re-examined and revised the species of subgenus Denticeradocus, and divided into 7 species. Now following his key to the species, my specimens fall into $C$. (D.) capensis. However, the identification do not necessarily fully content myself in the following respect, e.g. 
the lower hind corner of article 2 of peraeopods 3-5 rather similar to that of of rubromaculatus. SHEARD gave no full description and figures of this species, therefore the differences could not be fully examined.

Distribution: South Africa (off Cape Agulhas, $274 \mathrm{~m}$, and Table Bay).

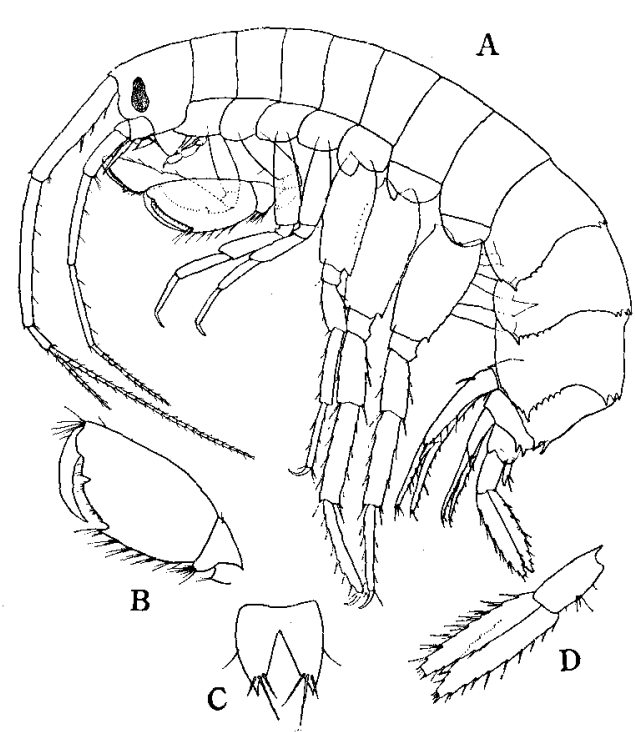

(Fig. 32)

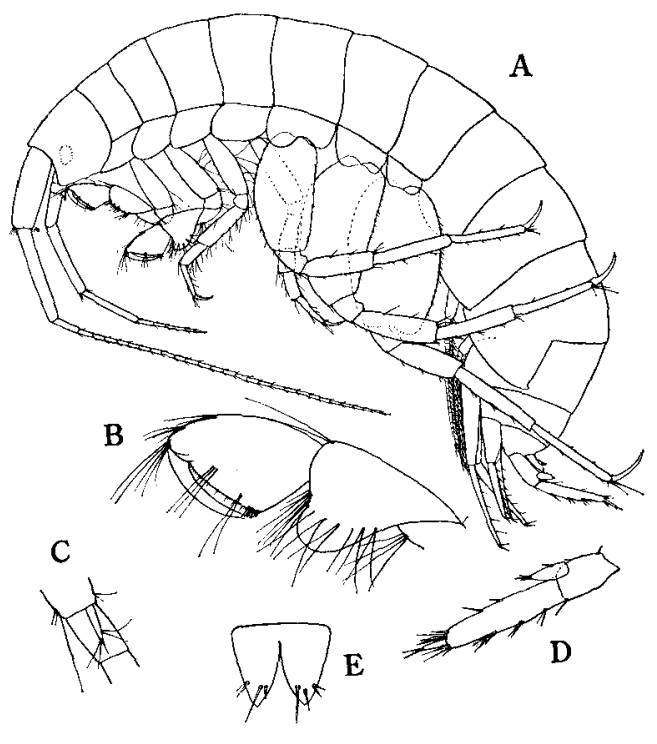

(Fig. 33)

Fig. 32. Ceradocus (D.) capensis SHEARD. A, lateral view of female; B, male gnathopod 2; C, telson; D, uropod 3.

Fig. 33. Eriopisella sechellensis (Chevreux). A, lateral view; B, gnathopod 2; C, accessory flagellum of antenna $1 ; \mathrm{D}$, uropod $3 ; \mathrm{E}$, telson.

\section{Eriopisa elongata (BRUZELIUS)}

Eriopisa elongata, Della Valle 1893, pl. 38, figs. 17-30 \& pl. 60, fig. 5; SARs 1895, pl. 181, fig. 2 ; Stebbing 1906, p. 411.

Material examined: Only one male specimen, $7.2 \mathrm{~mm}$ long; from St. 10 in Area V, $1.8 \mathrm{~m}$ in depth, Mar. 1956.

Remarks: The specimen is well allied to E. elongata figured by SARS, except for the following respects: Accessory flagellum of antenna 1 one-jointed, and reaching beyond the end of the first primary flagellar article; peduncle of uropods 1-2 relatively long, particularly that of uropod 1. much longer than the rami, just like in E. chilkensis (ChILton 1921a, p. 531, fig. 4, as in Niphargus c.) from Chilka Lake, India; Each expansion of article 2 of peraeopods 3-5 
like in E. elongata, but the posterior margin rather straight; the general appearance of peraeopods $1-5$ rather similar to $E$. chilkensis, except for article 2, particularly in the broader and stouter form of articles 4 and 5.

Otherwise, the specimen agrees entirely with E. elongata. Characteristic form of male gnathopod 2 of this specimen is very distinctive from both that of $E$. chilkensis figured by CHILTON (1.c.) and that figured by K. H. BARNARD taken from Lower Bengal (1935, p. 283, fig. 3).

Distribution: Lofoten Isles to Great Britain and Mediterranean.

\section{Eriopisella sechellensis (CHEVREUX)}

(Fig. 33)

Eriopisa sechellensis CHEvREux 1901, p. 403, figs. 19-23.

Niphargus chilkensis, (not CHILTON 1921a), CHILTON 1925, p. 534, fig. 1.

Eriopisella sechellensis, K. H. BARNARD 1935, p. 284, fig. 4; RUFFo 1958, p. 6, figs. 1-2.

Gammaridae undet. sp., NAGATA 1960 , p. 173 , pl. 15, figs. $72-79$ \& pl. 16, figs. $80-92$.

Material examined: Areas I (98), II (11), III (4), IV (201), VII (28), IX-d (2), X (9), XI-a (528), XI-b (35). Total: 916 specimens, up to $5.5 \mathrm{~mm}$ in length; from depths of Zostera belt near low water marks (where the tide does not entirely recede even in the spring tide) to $50 \mathrm{~m}$. Generally inhabiting abundantly on the mud or sandy mud bottom deeper than low water marks, as the members of Ampeliscidae.

Remarks: The specimens seem referable to the present species without much doubt. Re-examination of the specimens at hand is as follows: Eyes small, round, the facets in some fresh specimens composed of three, light red, reticulated with milky white. Gnathopods 1 and 2 ; article 6 rather closely resembles that of CHILToN's figures of Niphargus chilkensis than that of Chevreux's one of Eriopisa sechellensis, but the breadth of the article 6 is somewhat variable even in my specimens, although the shape is usually triangular and the palm is always longer than the hind margin. Peraeopods 3-5; finger nearly as described and figured by Chevreux, the shape unguiform, bearing one or two spinules at the base of the ungula (the slender form of the legs figured in my preceding paper was caused by not being depressed under the cover-glass). The apices of telson pretty variable in shape, rounded or pointed, sometimes rather notched just by the apical point. Coxa 1 sometimes strongly produced at the antero-distal corner as seen in Chevreux's figure.

J. L. BARNARD in his paper of 1962a (p. 110) created a new genus Netamelita having much close resemblance to the genus Eriopisella, from which it differs only in wanting the second article of the outer ramus of uropod 3 , and he says that the undetermined genus and species of Gammaridae described by 
me in 1960 should belong to the present new genus. However, he may have overlooked the genus Eriopisella, which perhaps be identical with Netamelita. In fact, Netamelita cortada, new species described therein appears to be much closely related to E. sechellensis figured by RUFFo (1.c.) in the similar shapes of articles 5 and 6 of gnathopods 1 and 2 .

Distribution: Seychelles Is. (Chevreux); Tale Sap, Siam (Chilton); Travancore, India (K. H. BARNARD).

\section{Megaluropus agilis HoEK}

Megaluropus agilis, Della VAlle 1893, pl. 34, figs. 1-17; STEBbing 1906, p. 420 ; ChevreuX \& FAGE 1925, p. 226, figs. 236-237; GuRJANOvA. 1951, p. 745, fig. 515.

Material examined: Area XI-b, 5 female specimens, up to $4.2 \mathrm{~mm}$ in leng th ; St. 22, 54-56 $\mathrm{m}$ in depth, Sept. 4, 1960.

Remarks: The specimens agree well with CHEvreUX \& FAGE's description and figures.

Distribution: Widely distributed along the European coasts; Kattegat, Holand, Firth of Forth, Liverpool Bay, English Channel, Bristol Channel, France, Gulf of Naples, and Black Sea.

\section{Family DEXAMINIDAE}

Key to the species of Dexaminidae

Lateral lobes of head with an acute point at apex Paradexamine barnardi

Lateral lobes of head rounded at apex Paradexamine findersi

\section{Paradexamine flindersi (STEBBING)}

Dexamine findersi STEBBING 1888, pl. 137c.

Guernea findersi, STEBBiNg 1906, p. 522, fig. 92.

Paradexamine findersi, Stebring 1910, p. 603, pl. 52 ; SheArd 1938, p. 185.

Material examined: Area IV, 8 specimens ( 6 females, 2 males) up to $5.8 \mathrm{~mm}$ in length; from depths of $10-25 \mathrm{~m}$.

Distribution: Flinders Passage, Bass Strait, $15 \mathrm{~m}$; off Port Hacking, and off Wata Mooli, 54-59 fathoms.

\section{Paradexamine barnardi SHEARD}

(Fig. 34)

Paradexamine barnardi SHEARD 1938, p. 178, fig. 6.

Paradexamine pacifica (non THOMSON), NAGATA 1960, p. 174, pl. 16, fig. 93.

Material examined: Areas I (1), IV (1643), V (11), VI (77), VII (72), IX-b (644), 
IX-d (875), XIII-a (2), XIII--b (48). Total: 3373 specimens, up to $6.0 \mathrm{~mm}$ in length. Abundantly found in Zostera belt near low water mark.

Remarks: After the Seto Inland Sea specimens had been referred to $P$. pacifica in my preceding paper (l.c.), Dr. K. SheARD kindly sent me his copy on the genus Paradexamine in which he analyzed strictly their distinction among the eight species of this genus.

According to his paper, the specimens are conformed with $P$. barnardi of the pacifica group. This species is much closely related to $P$. paciffca, but

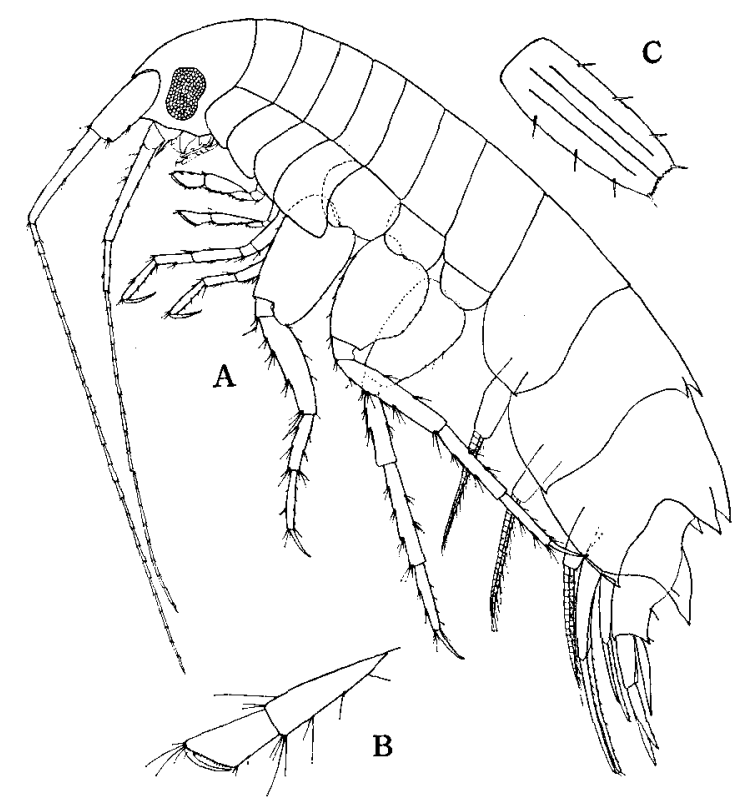

Fig. 34. Paradexamine barnardi SHEARD. A, lateral view of female; $B$, gnathopod $2 ; C$, telson.

distinguished by the following two characteristics; 1) gnathopod 2, article 5 more than 1.5 times as long as article 6,2 ) lower lip with one minute tooth on the apex of each outer lobe.

Distribution: Off Three Kings Islands, north of New Zealand (coll. by 'Terra Nova' Expedition). This species is also recorded by me from Zostera belt of Mutsu Bay, northern Japan.

Family TALITRIDAE

Qrchestia platensis japonica (TATTERSALL) 
Talorchestia japonica TATTERSALl 1922, p. 452, pl. 21, figs. 1-10.

Orchestia japonica, STEPHENSEN 1935, p. 6.

Orchestia platensis japonica IWASA 1939, p. 261, pl. 10 \& text-figs. 4-6; STEPHENSEN 1944, p. 59, fig. 17 .

Material examined: A large number of specimens from high water marks of Area IX; max. $14.3 \mathrm{~mm}$ long, male (see Part II).

Distribution: Widely distributed on the beach of Japan from Hokkaidô (Wakkanai) to Danzyô Is., west of Kyûshû ; sometimes limicolous, terricolous.

\section{Family HYALIDAE}

Key to the species of Hyalidae

1. Gnathopod 2 in male, article 5 masked behind by article 4

1. Gnathopod 2 in male, article 5 produced between articles 4 and 6

2. Finger of peraeopods minutely pectinate

2. Finger of peraeopods smooth, not pectinate

3. Antenna 2 strongly feathered below

3. Antenna 2 not feathered below 2 Hyale schmidti Allorchestes plumicornis Allorchestes angustus

\section{Hyale grandicornis (KR $\mathrm{YER}$ )}

Hyale prevostii (part), Della VAlle 1893, pl. 2, fig. 6 \& pl. 16, figs. 23-42.

Nicea novaezealandiae THOMSon 1879, p. 235, p1. 10-B, figs. 1, a-f.

Hyale novaezealandiae, STEBBING 1906, p. 567 ; IWASA 1939, p. 276, pl. 16 \& text-fig. 16.

Hyale grandicornis, STEBBING 1906, p. 566 ; K. H. BARNARD 1916, p. 230 ; RUFFO 1950, p. 55 ; K. H. BARNARD 1955, p. 93, fig. 46 ; HURLEy 1957, p. 904, figs. 1-23 (with two forms novaezealandiae and thomsoni).

Material examined: Area XIV, 11 specimens, up to $10 \mathrm{~mm}$ in length ; among algae near low water marks, May 31, 1962.

Distribution: Chile (Valparaiso), New Zealand, South Africa, South Atlantic (Gough I.), S. W. of New Zealand (Macquarie I.), Antarctica (Commonwealth Bay), and Japan, where it is known by IwAsA, found among algae near low water marks from Hokkaidô to Kyûshu.

\section{Hyale schmidti (HELLER)}

Hyale schmidti, Stebbing 1906, p. 571; Chevreux 1911, p. 237, pl.16, figs. 9-12 ; Chevreux \& FAGE 1925, p. 288, fig. 299 ; IwASA 1939, p. 278, pl. 17 \& text-fig. 17.

Material examined: Area XIV, 30 specimens, up to $8.0 \mathrm{~mm}$ long; among algae near low water marks, May 31, 1962.

Distribution: Azores, Canary Is. (Tenerife), Portugal, and Mediterranean; Japan and the neighboring waters (Hokkaidô and Korea Strait), 


\section{Allorchestes angustus DANA}

Allorchestes angustus, J. L. BARNARD 1952, p. 20, pl. 5, figs. 2-6 ; J. L. BARNARD 1954a, p. 21, pl. 21.

Allorchestes malleolus STEBBing 1899, p. 409, pl. 33-A; IWASA 1939, p. 285, pl. 20, text-figs. 20-22.

Material examined: Area $\mathrm{X}$, only one male specimen, $9 \mathrm{~mm}$ long; St. 2, 20-23 $\mathrm{m}$ in depth, June 2, 1959.

Remarks: This species is also recorded by me from the inshore waters near Shirikishinai, Hokkaidô.

Distribution: East China Sea, Korea Strait, Japan Sea (E. of Korea) (StebBING, 1899); coasts of Oregon and California (DANA, Stimpson, Stout, and J. L. BARNARD). On the Japanese coast, found on the beaches of Akkeshi, Muroran and Birô in Hokkaidô, by IwasA.

\section{Allorchestes plumicornis (HELLER)}

Allorchestes plumicornis, StebBIng 1899, p. 412, pl. 33-C; STEBbing 1906, p. 583 ; CheVReux \& FAGE 1925, p. 291, fig. 302 ; IwASA 1939, p. 289, pl. 22, text-figs. 25-26 ; STEPHENSEN 1944 , p. 71 , fig. 25.

Material examined: One male specimen, ca. $8.0 \mathrm{~mm}$ in length, from the tide pool of Area IX, Jan. 20, 1958.

Distribution: Mediterranean, and Japan (Hokkaidô and Japan Proper).

\section{Family AORIDAE}

Key to the species of Aoridae

1. Antenna 1, accessory flagellum well developed Aora typica

1. Antenna 1, accessory flagellum absent or rudimentary

2. Gnathopod 1 in male densely setiferous Aoroides secunda

2. Gnathopod 1 in male not densely setose Aoroides columbiae

\section{Aora typica KR $\phi \mathrm{YER}$}

Aora typica, Thomson 1879a, p. 331 ; Thomson 1881, p. 216 ; Stebbing 1906, p. 587, fig. 101 ; Chevreux 1907, p. 510 ; Chevreux 1911, p. 242 ; Chilton 1911, p. 565 ; K. H. BARNARD 1916, p. 236 ; ChEVREUX \& FAGE 1925, p. 293, figs. 304-305.

Aora gracilis, SARS 1895, pl. 193.

Aora kergueleni StebBing 1888, pl. 109, figs. a, d.

Aora trichobostrychus STEBBING 1888, pl. 109, figs. b, c.

Microdeutopus maculatus THOMSON 1879a, p. 331, pl. 16, figs. 5-8; THOMSON 1881, p. 217, pl. 8, figs. $7 \mathrm{a}-\mathrm{c}$.

Material examined: Areas IV (17), VI (21), VII (30), XIII-b (5), Total: 73 specimens, up to $7.0 \mathrm{~mm}$ long. Found from Zostera belt near low water mạks 
to a depth of $5.5 \mathrm{~m}$ in low water.

Remarks: Male gnathopod 1 of a specimen of $6.5 \mathrm{~mm}$ long resembles fairly well in the general appearance that of SARS' figure of A. gracilis, but article 2 with a triangular tooth on the anterior margin as in New Zealand specimen described by Thomson (1881, p. 217); the apex of article 4 not always reaching the end of article 5 ; article 5 much elongate, longer than article 2, about 4 times as long as wide; article 6 about three fifths as long as article 5 , bearing a minute tooth at the postero-distal end, but has no spine on the posterior margin; finger about two thirds the length of article 6 ; several fascicles of long setae are seen on the distal end of article 6 .

Male gnathopod 2, female gnathopods 1-2, peraeopod 1, and the slender mandibular palp are all nearly like in those of A. trichobostrychus figured by Stebing. Pleonal epimera 1-3 each with a tooth at the lower hind corner, the tooth also seen in the third pleonal epimeron described and figured by Chevreux \& Fage. The palp of maxilla 1 lined with several simple, slender spines along the inner margin above half the length. The most peculiar feature of my specimens is that the lower lip has the principal lobes excavated on the same portion as seen in the species of Ampithoidae, and the mandibular process somewhat strongly constricted at the base. It is also noted that coxae 1-4 somewhat shallower in comparison with the corresponding peraeon segment than in SARs' figure of A. gracilis, and pleon segment 4 dorsally with a pair of seta. Antenna 2 and peraeopods $3-5$ are missing on all the specimens at hand.

Distribution: From the coast of Norway to South Africa; Mediterranean. Indian Ocean: Kerguelen Is. South Pacific: Australia, New Zealand, Chile, Gambier Archipelago, Kermadec Is., and Auckland Is.

\section{Aoroides columbiae WALKER}

Aoroides columbiae WALkER 1898, p. 285, pl. 16, figs. 7-10; STEBBING 1906, p. 586; J. L. BARNARD 1954a, p. 24, pl. 22 ; NAgATA 1960 , p. 175, pl. 16, fig. 94.

Aoroides californica ALDERMAN 1936, p. 63, figs. 33-38.

Material examined: Areas I (101), III (1), IV (580), V (14), VI (7), VII (72), IX-b (2), IX-d (55), XI-b (1), XII (27), XIII-b (6). Total : 866 specimens, up to $5.0 \mathrm{~mm}$ long; Zostera belt near low water mark to a depth of 20-25 m.

Distribution: Puget Sound, and California.

\section{Aoroides secunda GuRJanova}

Aoroides secunda Gurjanova 1951, p. 828, fig. 579.

Material examined: Areas IX-d (16), XIII-a (1), XIII-b (3); up to $5.0 \mathrm{~mm}$ long, found between near low water mark and $2 \mathrm{~m}$ line at the outside, 
Remarks: This species is characterised by male gnathopod 1 covered all over with a thick brush of plumose setae, but the specimens are not entirely conformed with GurJanova's description and figures. Eyes small, subtriangular (narrowing below). Antenna 1 without accessory flagellum; flagellum of antenna 2 with three joints, each tipped with a long curving strong spine. Mandibular palp very slight as in A. columbiae, but the article 2 about twice as long as article 1 , article 3 two thirds the length of article 2, and only furnished with two long setae on the top of article 3. Peraeopod 5 much longer and slender in proportion to his figure, and much longer than the preceding peraeopods. Telson longer than broad, narrowing distally, the apex rounding in male, excavated in female in dorsal view respectively, with $2-3$ setae on each side of the apex. Color whitish, with speckling of small black spots, particularly along the articulate line of body segments.

Distribution: Russian coast of the Japan Sea (intertidal zone of inlets).

\section{Family PHOTIDAE}

Key to the species of Photidae

1. Uropod 3 with inner ramus much smaller than the outer

1. Uropod 3 with the rami not very unequal

2. Lateral lobes of head little produced

2. Lateral lobes of head much produced
3. Antenna 1, accessory flagellum well de

3. Antenna 1, accessory flagellum obsolete Photis longicaudata

4. Gnathopod 2, article 6 broad, oval form Podoceropsis nitida

4. Gnathopod 2, article 6 narrow, club-shaped Eurystheus japonicus Eurystheus utinomii

\section{Photis reinhardi $\mathrm{KR} \phi \mathrm{YER}$}

Photis reinhardi, SARs 1895 , p. 569, pl. 202 ; STEBbING 1906, p. 607 ; SHOEMAKer 1930, p. 338 ; Stephensen 1940, p. 61 ; STEPHENSEN 1942, p. 369 ; Schellenberg 1942, p. 200, fig. 165 ; Stephensen 1944a, p. 23 ; Stephensen 1944b, p. 117 ; Shoemaker 1945, p. 3, fig. 1 ; GurJanova 1951, p. 843, fig. 590 .

Material examined: Areas IV (2185 specimens in total, putting together with Photis longicaudata), XI-a (59), XI-b (5). Length: up to $5.0 \mathrm{~mm}$. Found from depths of $1056 \mathrm{~m}$.

Distribution: A boreo-arctic species; in North Atlantic, south to the coast of Connecticut, and to North Sea; in North Pacific, through Bering Sea and Okhotsk Sea, to the Japan Sea.

\section{Photis longicaudata (BATE \& WESTwOOD)}

(Fig. 35) 
Photis longicaudata, SARS 1895, p. 571, pl. 203, fig. 1 ; WALKER 1904, p. 286, pl. 6, fig. 43 ; Stebing 1906, p. 608 ; Walker 1909, p. 339 ; Chevreux 1911, p. 249 ; Stephensen 1915, p. 51 ; Chevreux \& Fage 1925, p. 310, fig. 319 ; Schellenberg 1926a, p. 231 ; Schellenberg 1928, p. 662 ; K. H. BARNARD 1937, p. 164 ; Schellenberg 1942, p. 201, fig. 166 ; Shokmaker 1945, p. 11, fig. 5 ; ReID 1951, p. 262.

Material examined: Areas IV (2185 specimens in total, putting together with Photis reinhardi), XI-a (106), XI-b (9); up to $8.0 \mathrm{~mm}$ in length; from depths of $10-56 \mathrm{~m}$.

Distribution: From the south-west coast of Norway, along the European coasts, southwards to the tropical coast of West Africa; Gulf of Mexico;

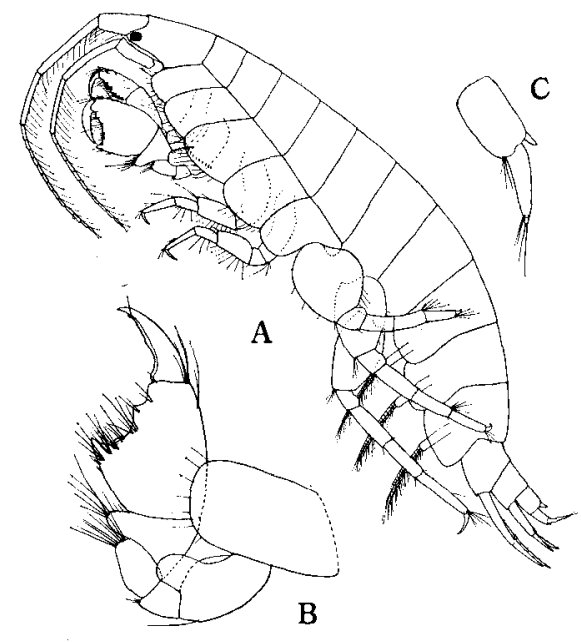

(Fig. 35)

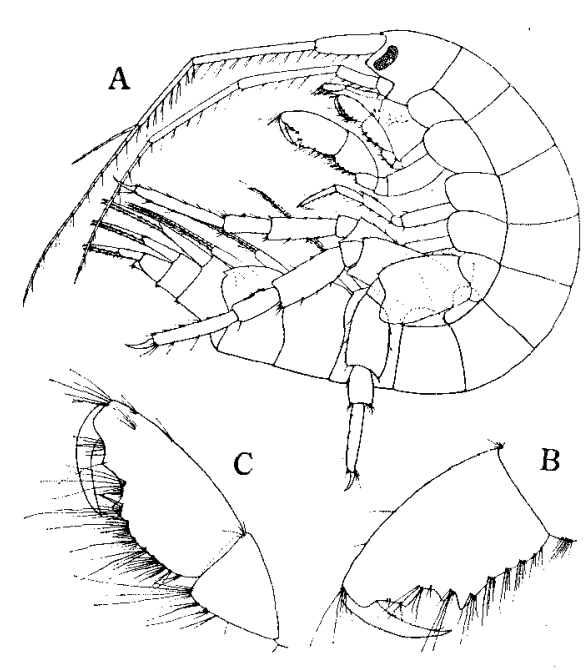

(Fig. 36)

Fig. 35. Photis longicaudata (BATE \& WESTwOOd). A, lateral view of male; B, male gnathopod 2 ; C, uropod 3.

Fig. 36. Eurystheus japonicus NAGATA. A, lateral view of male; B, male gnathopod 2 ; C, female gnathopod 2.

Mediterranean and Suez Canal ; on the coast of Indian Ocean, South Arabian coast, British East Africa, Amirante, Seychelles, Cargados, Ceylon, and Chilka Lake. Also known from the west coast of Greenland, and Franz Josef Land, according to Schellenberg (1942).

\section{Eurystheus japonicus NAGATA}

(Fig. 36)

Eurystheus japonicus NaGATA 1961a, p. 32, fig. 1. 
Material examined: Areas IV (10), VI (12) XI-a (1), XI-b (3), XIII-a (1); up to $8.0 \mathrm{~mm}$ in length; from depths of $2-46 \mathrm{~m}$.

Distribution: Known only from Japan; Mutsu Bay to the west coast of Kyûshû.

\section{Eurystheus utinomii NaGATA}

(Fig. 37)

Eurystheus utinomii NAGATA 1961a, p. 34, fig. 2.

Material examined: Areas IV (1702), XI-a (56), XI-b (3); up to $8.5 \mathrm{~mm}$ in length; from depths of $10-56 \mathrm{~m}$.

Distribution: Known only from Japan; also found off Tsuyazaki, Kyûshû by me.

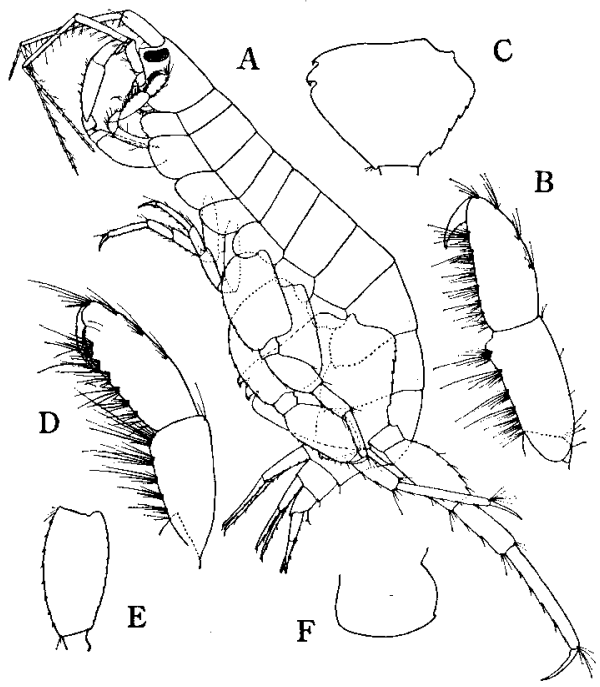

(Fig. 37)

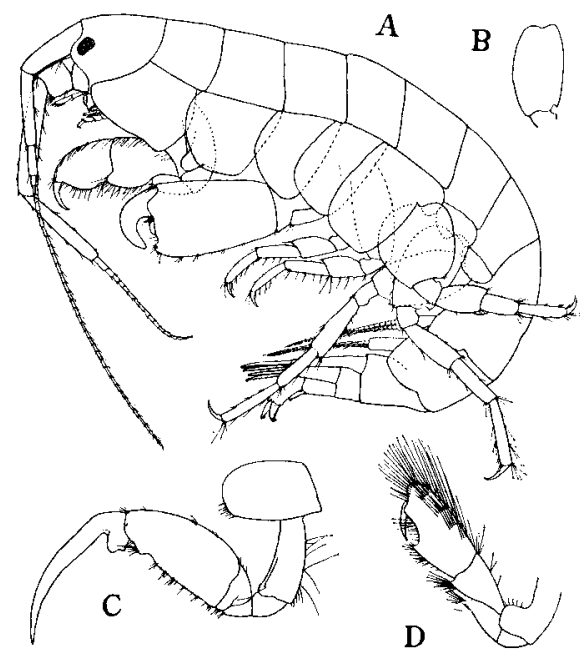

(Fig. 38)

Fig. 37. Eurystheus utinomii NAGATA. A, lateral view of male; B, male gnathopod 2; C, article 2 of male peraeopod 5; D, female gnathopod 2; E, article 2 of female peraeopod $5 ; \mathrm{F}$, pleonal epimeron 3 .

Fig. 38. Ampithoe valida SMith : A, lateral view of male; B, article 2 of peraeopod 4. Ampithoe orientalis DANA: C, male gnathopod 2. Ampithoe ramondi AudouIN: $\mathrm{D}$, male gnathopod 2 .

\section{Podoceropsis nitida (STIMPSON)}

Podoceropsis excavata, SARS 1895, p. 576, pl. 205.

Podoceropsis nitida, Holmes 1908, p. 543; Stebring 1906, p. 620 ; Chevreux \& Fage 1925, p. 317 , fig. 326 ; Shoemaker 1930 , p. 342 ; SChEllenderg 1942, p. 194, fig. 161 ; STEPHENSEN 1944a, p. 26 ; Gurjanova 1951, p. 855, fig. 600. 
Material examined: Areas XI-a (2), XI-b (2); up to $9.0 \mathrm{~mm}$ in length; from depths of $47-56 \mathrm{~m}$.

Distribution: From Norwegian coast, around Faroes and Iceland, to Great Britain and France; Davis Strait to Rhode Island; East Siberian Sea, Chukot Sea, Bering Sea, Alaska (Alitak Bay, Kadiak Bay), and Japan Sea (Bay of the Great Peter).

\section{Family AMPITHOIDAE}

Key to the species of Ampithoidae

1. Third pleonal epimeron with the lower hind corner produced into a small, rounded tooth Ampithoe lacertosa

1. Third pleonal epimeron with the lower hind corner rounded

2. Gnathopod 2 in male, palm transverse Ampithoe valida

2. Gnathopod 2 in male, palm oblique

3. Gnathopod 2 in male, palm defined by a conspicuous tooth from the posterior margin

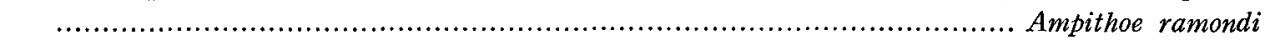

3. Gnathopod 2 in male, palm undefined from the hind margin Ampithoe orientalis

\section{Ampithoe lacertosa BATE}

Ampithoe lacertosa, Delia valle 1893, pl. 57, fig. 37 ; STEBbing 1906, p. 633 ; J. L. BARNARD 1954a, p. 31, pls. 29-30; NAGATA 1960, p. 175, pl. 16, figs. 95-96. Amphithoe macrurus STEPHENSEN 1944, p. 80, figs. 30-31. Amphithoe japonica Stebbing 1888, p. 1124, pl. 138-A ; GuRjanova 1951, p. 895, fig. 621.

Material examined: Areas IV (909), V (32), VI (26), VII (24), IX-a (7), IX-b (51), IX-c (5), IX-d (1), XIII-a (2), X III-b (19), XIV (1). Total: 1077 specimens, up to $25.0 \mathrm{~mm}$ in length. Popular among algae or eelgrass in Zostera belt near low water marks, and also found among the floating kelp.

Remarks: Amphithoe macrurus StePhensen from Port Shimizu of Japan is referred to A. lacertosa by J. L. BARNARD in his paper of 1954a. In Challenger Report of 1888, Stebbing described a new species, $A$. japonica from Kôbe Bay of the Seto Inland Sea, and his description is based on the three specimens comprising only females. I have had a large number of materials referred to A. japonica from the other various localities of the Japanese coast as well as from the Seto Inland Sea, and it is unable to be distinguished A. lacertosa at all from the present female specimens of $A$. japonica in the essential characters; for instance, in the forms of gnathopods $1-2$, in the powerful peduncle of uropod 3, and moreover in having a small tooth at the lower hind corner of the third pleonal epimeron, the last character is said by J. L. BARNARD to be unique in the species of this genus.

On the other hand, GuRjanova in his paper of 1951 described a male of A. japonica, and the male gnathopod 2 figured therein appears to have no 
particular difference in the structure from those of both $A$. lacertosa figured by J. L. Barnard and $A$. macrurus by Stephensen. He says there that $A$. japonica is widely distributed in the Japan Sea, found among seaweed on the bottom between $0-50 \mathrm{~m}$ in depth along the coasts of Hokkaido and the Russian side of the Japan Sea. I have already mentioned briefly in my preceding paper about the northern specimens of Japan of A. lacertosa found from the insîne waters near Shirikishinai, east of Hakodate, Hokkaido, whose male gnathopod 2 has such a cheliform component as figured by J. L. BARNARD (1954a, pl. 29, F), and those northern ones are otherwise entirely the same as those from the Seto Inland Sea in their characters. Even among Seto Inland Sea specimens, a slight indication of the transition to cheliform could be occasionally seen in the larger ones more than about $20 \mathrm{~mm}$ long. Differences of the relation between the degree of the chelate formation and the size of animals, or relative length of the peduncle of uropod 3 to the rami, are probably due to those of each environmental condition in the various localities inhabited by the animals. Stebring says in the last part on the new species, "The great similarity which prevails among the more or less definitely ascertained species of this genus, and the scantiness of the details which in many instances have been thought sufficient for their identification, necessarily leave new species on a very insecure footing. To review all the species of Amphithoe will be a task by itself for any one who is willing to undertake it." It is, thus, pretty sure that $A$. japonica is a synonym of $A$. lacertosa, and the former is only a stage in the process of development towards the latter.

Distribution: A boreo-arctic form; to Oregon southwards on the Pacific coast of North America, and to the Japan Sea in the north-western Pacific.

\section{Ampithoe valida $\mathrm{Smith}$}

(Fig. 38, A-B)

Ampithoe valida, Stebbing 1906, p. 635 ; Alderman 1936, p. 68 ; J. L. Barnard 1954a, p. 34 , pl. 31 ; NAGATA 1960 , p. 176 , pl. 16, figs. 97-98.

Amphithoe shimizuensis STEPHENSEN 1944, p. 77, figs. 28-29.

? Ampithoe mitsukurii Della Valle 1893, pl. 57, figs. 30-32.

Material examined: Areas IV (539), V (1), IX-b (2); up to $20.0 \mathrm{~mm}$ in length. Found in Zostera belt near low water marks.

Remarks: According to Stebbing's mention in his "Tierreich", A. mitsukurii is known from Japan, and judging from Della VALLE's figures, this species is probably identical with $A$. valida. His text is, unfortunately, unavailable to me.

Distribution: North Atlantic; New Jersey and Long Island Sound. In North Pacific, from California, Oregon, and Japan. Mediterranean (?). 


\section{Ampithoe ramondi AUDOUIN}

(Fig. 38, D)

Ampithoe ramondi, SCHELlENBERg 1928, p. 665 ; K. H. BARNARD 1935, p. 305 ; K. H. BARNARD 1937, p. 170 ; Pirlot 1938, p. 346 ; Schellenberg 1938, p. 87 ; K. H. Barnard 1940, p. 480 ; SHOEMAKer 1942, p. 40 ; J. L. BARNARD 1955, p. 28.

Ampithoe vaillantii, WALKer 1904, p. 291 ; Stebbing 1906, p. 639 ; Chevreux 1911, p. 260 , pl. 20, figs. 1-4 ; STEPHENSEN 1915, p. 51 ; K. H. BARNARD 1916, p. 253 ; ChEvreuX \& FAGE 1925, p. 333, figs. 341-342; GURJANOVA 1951, p. 880, fig. 614 .

Amphithoe intermedia WALKER 1904, p. 290, pl. 7, fig. 46; WALKER 1909, p. 341 ; ChevreuX 1907, p. 515, fig. 29 ; SHOEMaker 1921, p. 102.

Amphithoe lobata WALKER 1909, p. 342, pl. 43, fig. 9.

Ampithoe divisura SHOEMAKER 1933, p. 255, fig. 9.

Material examined: Areas IX-b (4), IX-c (3), IX-d (8), XIII-a (6), XIII-b (4), XIV (4). Total: 29 specimens, up to $8.5 \mathrm{~mm}$ in length. Found among sea weed in depths of low water mark to $4 \mathrm{~m}$.

Distribution: Very frequent in the tropical and subtropical seas.

\section{Ampithoe orientalis DANA}

(Fig. 38, C)

Ampithoe orientalis, Stebbing 1906, p. 641 ; J. L. Barnard 1955, p. 26, fig. 14.

Material examined: Areas XIII-a (1), XIII-b (1); $8.0 \mathrm{~mm}$ and $9.5 \mathrm{~mm}$ in length, both males, found in the Zostera belt near low water marks.

Distribution: Philippine Is. and Hawaiian Is.

\section{Family ISCHYROCERIDAE}

Key to the species of Ischyroceridae

Coxa 5 much deeper than coxa 6 Jassa falcata

Coxa 5 not much deeper than coxa 6 Microjassa cumbrensis

\section{Jassa falcata (MontAGU)}

Jassa falcata, SEXTON \& REID 1951, pp. 29-91, pls. 4-30 (with many references).

Material examined: Areas IX-d (1), XII (43); up to $5.0 \mathrm{~mm}$ in length.

Distribution: Cosmopolitan, except for the polar circles.

\section{Microjassa cumbrensis (SteBbING \& ROBERTSON)}

Podocerus cumbrensis Stebing \& Robertson 1891, p. 38, pl. 6, B.

Microjassa cumbrensis, StebBing 1906, p. 651 ; Chevreux \& FAGE 1925, p. 350, fig. 358. 
Material examined: One female specimen, $2.5 \mathrm{~mm}$ long from Area IX-d.

Remarks: Three species of this genus have hitherto been known: $M$. macrocoxa Shoemaker (1942, p. 44, figs. 16-17), M. litotes J. L. BARNARD (1954, p. 127 , pls. 35-36), and the present species. The specimen is undoubtedly referred to this species, for I have examined several specimens of the species (up to $4.5 \mathrm{~mm}$ long, including males) from Ariake Sea, the west coast of Kyûshû, and the male gnathopod 2 agrees well with that of Chevreux \& FAGE's figure.

Distribution: Known from the coasts of England and France.

\section{Family COROPHIIDAE}

Key to the species of Corophiidae

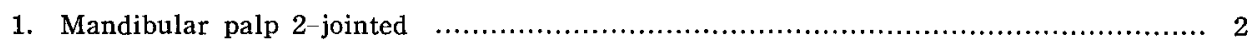

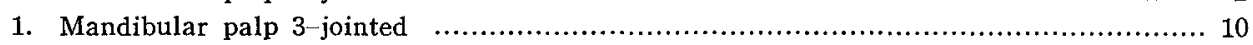

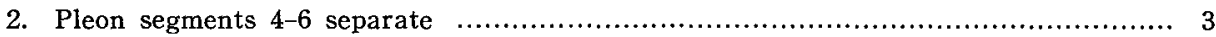

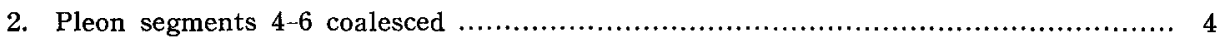

3. Uropod 3, ramus ovate ................................................ Corophium volutator

3. Uropod 3, ramus long and narrow ................................... Corophium kitamorii

4. Lateral lobes of head acute .................................... Corophium crassicorne

4. Lateral lobes of head not acute .................................................... 5

5. Antenna 2, peduncular article 4 with a large terminal tooth ........ (Male) ............ 6

5. Antenna 2, peduncular article 4 without such a tooth ............. (Female) ............. 8

6. Rostrum triangular, short ..................................... Corophium acherusicum

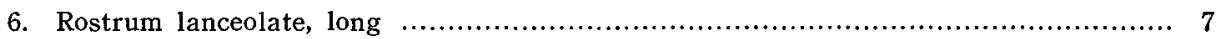

7. Antenna 1, peduncular article 1 with a blunt outgrowth on inner surface about opposite middle of rostrum

Corophium insidiosum

7. Antenna 1 , peduncular article 1 without such a outgrowth Corophium uenoi

8. Antenna 2, peduncular article 4 with spines set in a single row ..... Corophium uenoi

8. Antenna 2, peduncular article 4 typically with spines set in pairs, except the terminal. 9

9. Antenna 2, peduncular article 4 typically with 3 pairs of spines and a single terminal one Corophium acherusicum

9. Antenna 2, peduncular article 4 typically with 2 pairs of spines and a single terminal one Corophium insidiosum

10. Uropod 3, ramus much shorter than peduncle ....................................... 11

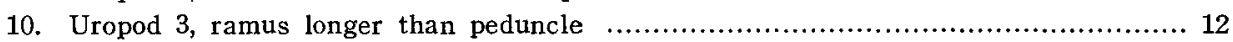

11. Uropod 2 biramous

Ericthonius pugnax

11. Uropod 2 uniramous Cerapus tubularis

12. Third pleonal epimeron with the lower posterior corner quadrate Grandidierella japonica

12. Third pleonal epimeron with the lower posterior corner completely rounded ......... Unciolella lunata

\section{Corophium volutator (PALLAS)}

Corophium volutator, STEBBING 1906, p. 686; CHevreux \& FAGE 1925, p. 364, figs. 371-372; CRAWFORd 1937, p. 595; SCHELLENBERg 1942, p. 218, fig. 177 ; STEPHENSEN 1942, p. 409 ; Shoemaker 1947 , p. 51, fig. 1, k-n; GurJanova 1951, p. 981, fig. 683. 
Corophium grossipes, SARS 1895, pl. 219.

Corophium bicaudatum, Della Valle 1893, pl. 56, figs. 2-6.

Material examined: Area II, 24 specimens, up to $5.8 \mathrm{~mm}$ in length.

Remarks: There is nothing to remark particularly here, except for the first peduncular article of antenna 1 , which is armed usually with only a spine on the lower margin near the distal end.

Distribution: From W. Norway, along the European coast, into Mediterranean, to Adriatic Sea and Black Sea (Sea of Azov); the coast of Senegal; Bay of Fundy, aud Maine.

\section{Corophium acherusicum CoSTA}

Crophium acherusicum, CHEvREUx 1911, p. 271 ; K. H. BARNARD 1916, p. 272 (part); ChEVREUX \& FAGE 1925, p. 368, fig. 376; CRAWFORD 1937, p. 617, fig. 2-P; SHOEMAKER 1947, p. 53, figs. 2-3 ; ShoEmaker 1949, p. 76 ; ReId 1951, p. 269 ; GuRJanova 1951, p. 977, fig. 680 ; J. L. BARNARD 1954a, p. 36 ; HURLEY 1954a, p. 442, figs. 35-39; J. H. BARNARD 1955, p. 37 ; IRIE 1956, p. 5, fig. 6; NAGATA 1960, p. 177.

Material examined: Areas I (5), IV (979 in total, putting together with both C. insidiosum and C. uenoi), V (1), VI (5), VII (1), VIII (1), IX-d (23), XII (56); all up to $5.5 \mathrm{~mm}$ in length.

Distribution: From the European coast to the tropical West Africa; Mediterranean and Black Sea; Suez Canal ; the coast of East Africa (Dar-esSalaam andDurban Bay); Baffin Bay to Brazil ; British Columbia to California ; Hawaiian Is., New Zealand, Hong Kong (from a ship's bottom), and Japan.

\section{Corophium crassicorne BRUZELIUS}

Corophium crassicorne, SARS 1895, pl. 220; WALkER 1904, p. 294 ; STEBbing 1906, p. 690, figs. 116-118; ChILTON 1925, p. 538 ; ChevREUX \& FAGE 1925, p. 367. fig. 375; CRAwFORD 1937, p. 607, fig. 4, a-f; STEPHENSEN 1942, p. 410 ; STEPHENSEN 1944b, p. 132 ; Shoemaker 1947, p. 53, fig. 4 ; Shoemaker 1949, p. 76 ; GurJanova 1951, p. 976 , fig. 679 .

Material examined: St. 20 in Area XI-b, 5 specimens (one juvenile, four females, ovig.), 2.5-3.7 mm in length ; 47-52 $\mathrm{m}$ in depth, Sept. 4, 1960.

Distribution: Jan Mayen, Murman Coast (Kola Bay), Barents Sea, White Sea, East Greenland ; from Norwegian coast and Faroes, along the European coast to the Black Sea, by far extending to Ceylon and Tale Sap; on the east coast of North America, from Bay of Fundy to New York (Long Island); on the Pacific coast, Alaska (Chichagof I.), E. of Kamchatka, and the Japan Sea.

\section{Corophium uenoi STEPHENSEN}

Corophium uenoi STEPHENSEN 1932, p. 414, figs. 3-4; CRAWFORD 1937, p. 616; J. L. BARNARD 1952, p. 28, pls. 8-9; J. L. Barnard 1959c, p. 39 ; NaGata 1960, p. 178. 
Material examined: Areas IV (see C. acherusicum), IX-d (47), XI-a (20), XIII-a (1), XIII-b (16); all up to $5.5 \mathrm{~mm}$ in length.

Distribution: Japan and California.

\section{Corophium insidiosum $\mathrm{C}_{\mathrm{RAWFORD}}$}

Corophium insidiosum CRAwFORD 1937, p. 615, fig. 2, a-g ; SHOEMAKER 1947, p. 53, figs. 6-7 ; SHOEMAKER 1949, p. 77 ; J. L. BARNARD 1959c, p. 38 ; NAGATA 1960, p. 177.

Material examined: Areas IV (see C. acherusicum), up to $4.7 \mathrm{~mm}$ in length.

Distribution: England, Denmark, Germany, and Italy; on the west coast of North America, Massachusetts (Newburyport) and New York (Amityville, Long Island); on the Pacific coast, Washington to Chile (Talcahuano); and Japan.

\section{Corophium kitamorii, sp. nov.}

(Fig. 39)

Material examined: Areas I (2), III (4), IV (6), VI (2), X (1), XI-a (3). Total : 18 specimens, $3.9-6.0 \mathrm{~mm}$ in length, from depths of $3-49 \mathrm{~m}$.

Description: Segments of urosome separate. Head with the front broadly convex, without a true rostrum; lateral lobes of head narrowly rounding at the apex; eyes not well developed (eyes position figured here are not right, and they are properly placed into lateral lobes). Antenna 1 rather slender; in male about as long as the head to pleon segment 2 combined; peduncular article 1 subequal in length to article 2, expanded on the upper surface, bearing an outgrowth near the base of the inner edge, and two spines on the lower edge, one near the outgrowth, the another near the distal end; peduncular article 3 one half the length of the article 2 ; flagellum 11-jointed, about as long as peduncular articles 2 and 3 combined. Antenna 2 of a single male specimen unfortunately missing. Antenna 1 in female a little longer than antenna 2; the first peduncular article shorter than the second and third combined, bearing 2-5 spines on the proximal half of the inner edge, and 3-4 spines on the lower edge; flagellum with 11-12 joints, nearly as long as peduncular articles 1 and 2 combined, Antenna 2 in female bearing 3-4 spines on the lower edge of the fourth article of peduncle, the fifth without spines, flagellum 3 -jointed.

Gnathopod 1 nearly like in C. annulatum Chevreux (1908, p. 73, figs. 4-5). Gnathopod 2 in male; finger long and slender, curved, nearly two thirds as long as article 6, otherwise gnathopod 2 rather like in C. aculeatum Chevreux (1908, p. 70, figs. 1-3) than in C. annulatum, particularly in relatively narrower article 6. Gnathopod 2 in female nearly like in male, except that finger very 
narrow and delicate, not curved but linear, slightly narrowing towards the distal end, which is not acute, bearing two long setae.

Peraeopods 1 and 2 ; article 5 proportionally long, about as long as article 4, finger shorter than article 6. Uropod 3, ramus narrow, longer than peduncle, both margin spinose.

Holotype: $\mathrm{KN}$ No. 2979, male, $4.6 \mathrm{~mm}$. Type locality: St. 9 in Area XI-a,

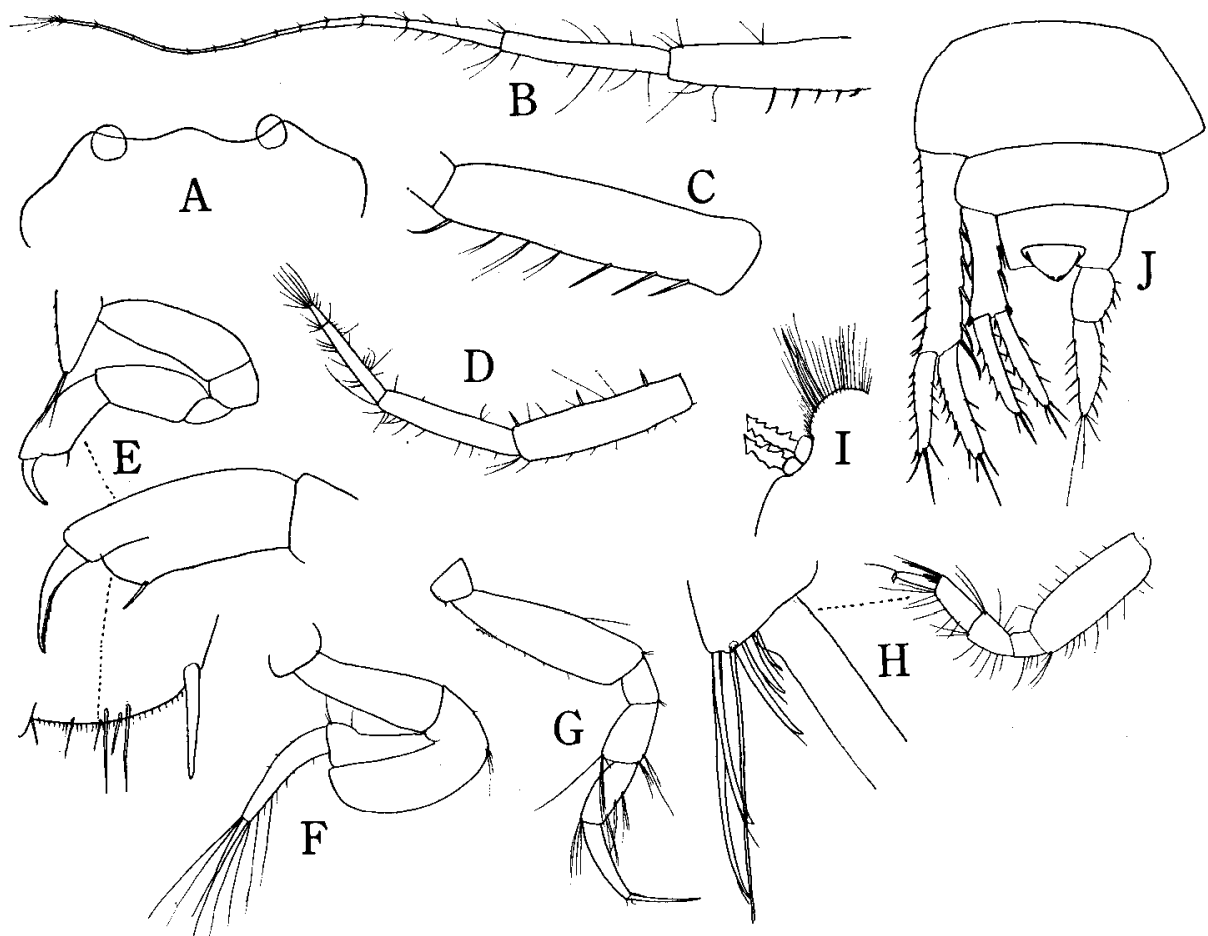

Fig. 39. Corophium kitamorii, sp. nov. Female, $6.0 \mathrm{~mm}$ : A, front of head, upper view; $B$, right antenna 1, upper view; $C$, right antenna 1, peduncular article 1 magnified, inner side view; E, F, gnathopods 1 and 2 ; I, inner side of peduncle of pleopod 3 ; $\mathrm{J}$, urosome and uropods $1-3$. Female, $5.0 \mathrm{~mm}: \mathrm{D}$, left antenna 2, articles 4 and 5 of peduncle, and flegellum, inner side view; $G$, peraeopod $1 ; \mathrm{H}$, peraeopod 3 , with posterodistal corner of article 5 magnified.

$42-49 \mathrm{~m}$ in depth, June $14,1959$.

Remarks: The new species is closely related to $C$. annulatum CHEvreux in having no true rostrum, and in having the outgrowth on peduncular article 1 of male antenna 1 , but differs from the latter in the poorly developed eyes, in the finger of female gnathopod 2, and in comparatively long article 5 of peraeopods $1-2$. 


\section{Ericthonius pugnax DANA}

(Fig. 40)

Ericthonius pugnax, Stebiing 1906, p. 672; Pirlot 1938, p. 352 ; HURLey 1954a, p. 445, figs. 40-61 ; NAGATA 1960 , p. 179, pl. 17, figs. 99-102.

Material examined: Areas I (1), IV (33), VI (15), VII (2), IX-b (2), IX-d (43), XII (37), XIII-a (4), XIII-b (71). Total : 208 specimens, up to $7.5 \mathrm{~mm}$ in length, from depth of $2 \mathrm{~m}$ in low wafer.

Distribution: Sulu Sea (Dana), East Indiès (Pirlot), New Zealand (HurLey), and Japan.

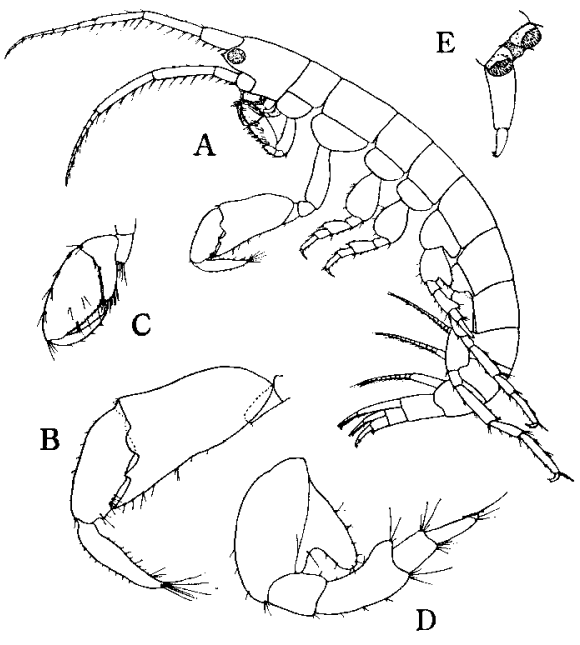

(Fig. 40)

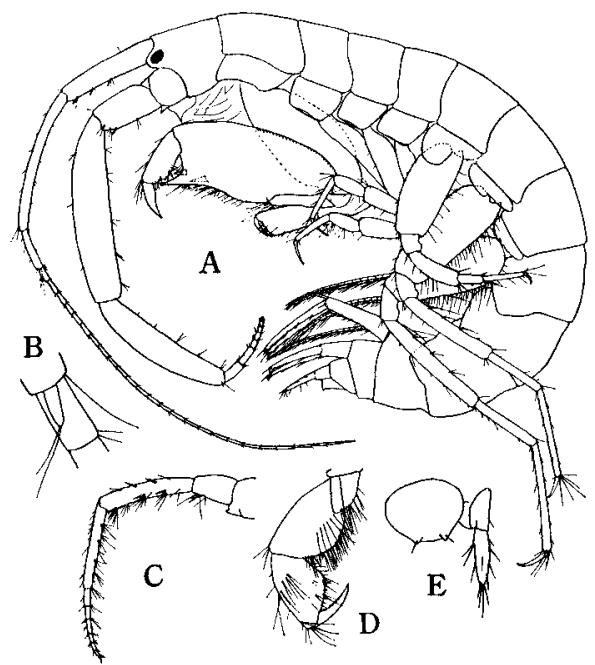

(Fig. 41)

Fig. 40. Ericthonius pugnax DANA. A, lateral view of male; B, male gnathopod 2; C, female gnathopod 2; C, female gnathopod 2; D, peraeopod 3; E, uropod 3 and telson.

Fig. 41. Grandidierella japonica Stephensen. A, lateral view of male; $\mathrm{B}$, accessory flagellum of antenna 1 ; C, antenna 2 of female; D, female gnathopod 1 ; E, uropod 3 and telson.

\section{Grandidierella japonica STEPHENSEN}

(Fig. 41)

Grandidierella japonica StePhenSEN 1938, p. 179, figs. 1-2; NAGATA 1960, p. 179, pl. 17, fig. 103.

Material examined: Areas I (6), II (12), IV (2023), V (49) VI (4), VII (78), VIII (19), IX-b (1), IX-d (45). Total : 2237 specimens, up to $12.0 \mathrm{~mm}$ in length; from the depth of about $10 \mathrm{~m}$ at the deepest, 
Distribution: Known only from Japan.

\section{Cerapus tubularis SAY}

(Fig. 42)

Cerapus tubularis, ShOEmaker 1942, p. 48; J. L. BarNard 1962b, p. 61, figs. $28-29$.

Cerapus abditus, Stebing 1910, p. 616, pl. 55A ; Pirlot 1938, p. 349, figs. 157-158.

Cerapus erae Bulycheva 1952, p. 248, fig. 39.

Material examined: Area IV, 45 specimens, up to $5.3 \mathrm{~mm}$ long; from the depth of $25 \mathrm{~m}$ at the deepest.

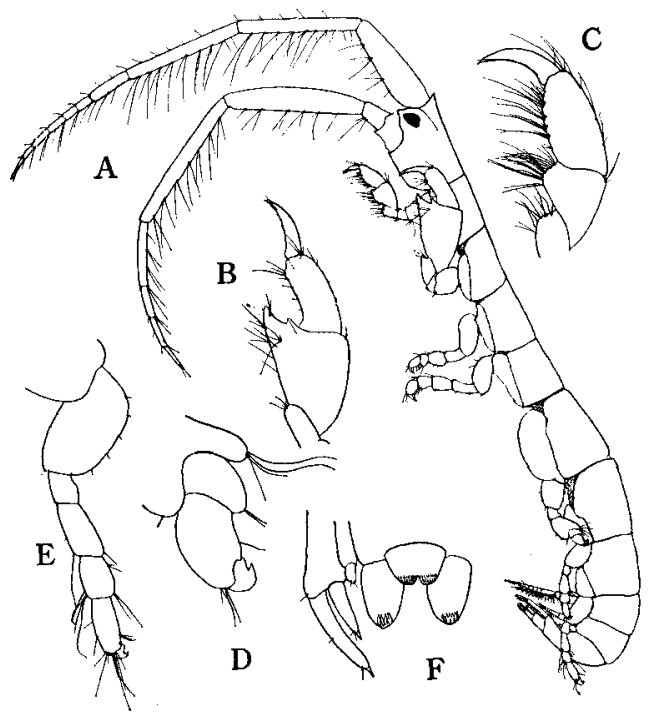

(Fig. 42)

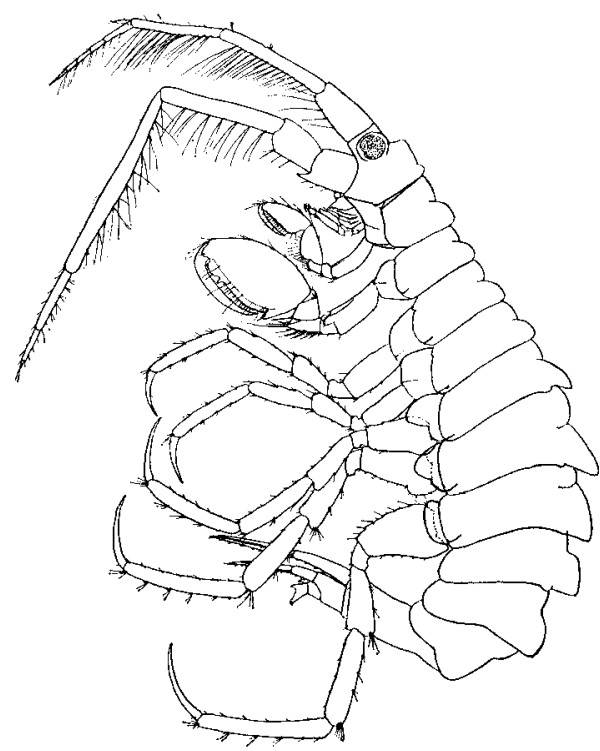

(Fig. 43)

Fig. 42. Cerapus tubularis SAY. A, lateral view of male; B, male gnathopod 2; C, female gnathopod $2 ; \mathrm{D}$, articles $4-7$ of peraeopod $3 ; \mathrm{E}$, peraeopod $5 ; \mathrm{F}$, telson and uropods $1-3$.

Fig. 43. Podocerus inconspicuus (STEBBING).

Distribution: East coast of North America (New Jersey, Vineyard Sound, and Connecticut); Pacific coast of North America (southern California, and Lower California); South Africa; Indian Ocean (Mauritius?); Ceylon, and Bengal; Indonesia; North Australia, and New South Wales.

\section{Unciolella lunata CHEVREUX}

Unciolella lunata CHEvREux 1911, p. 264, text-fig. 16 \& pl. 20, figs. 5-16; SCHELLENBERG 1928 , p. 669 , fig. 207 , 
Material examined: Areas IV (20), XI-b (8); up to $5.0 \mathrm{~mm}$ in length, all female ; from depths of $10-54 \mathrm{~m}$.

Remarks: It seems to be fairly questionable whether male gnathopod 1 figured by Schellenberg is that of male of the present species or not, for it resembles much closely that of members of the genus Grandidierella, and in Unciolella feveolata K. H. BARNARD (1955, p. 97, fig. 49), their gnathopods 1-2 are nearly alike in both sexes. Schellenberg says in his paper, "a pair of large male gnathopod 1 is lying loose with the materials." The specimens at hand are, to my regret, all female, and therefore I could not confirm the account described by Schellenberg.

My specimens agree fairly well with CHevreux's description and figures, except for the following respects: Mandibular palp more fully elongate; both gnathopods of nearly equal in size, having two small spines at the palmar angle of article 6; accessory flagellum of antenna 1 bearing 2-3 articles; finger of peraeopods 1-2 comparatively short, about a half the length of article 6.

Distribution: Algeria (Chevreux) and ? Suez Canal (Schellenberg).

\section{Family PODOCERIDAE \\ Podocerus inconspicuus (STEBBING)}

(Fig. 43)

Platophium inconspicuum StebBINg 1888, p. 1194, pl. 131.

Podocerus inconspicuus, STEBbing 1906, p. 702 ; PIRLOT 1928, p. 356, fig. 160 ; K. H. BARNARD 1940 , p. 483.

Podocerus palinuri K. H. BARNARD 1916, p. 277, pl. 28, fig. 23 ; K. H. BARNARD 1937, p.: 175, fig. 18.

Podocerus sp., Nagata 1960 , p. 179 , pl. 17, figs. 104-112.

Material examined: Areas IV (39), VI (14), XI-a (1); up to $8.9 \mathrm{~mm}$ long; found from depths of 2-42 m.

Remarks: Identification for the species of this genus is truly difficult in so far as the references are available. The present specimens are here referred to $P$. inconspicuus by nearly complete agreement with male and female gnathopod 2 figured by PIRLOT.

Distribution: Port Jackson, New South Wales (Stebbing); South Africa (K. H. Barnard); South Arabian coast (K. H. Barnard); East Indies (Pirlot), and Japan.

\section{ZOOGEOGRAPHICAL NOTE}

83 species and 2 subspecies of gammaridean amphipods were found in the Seto Inland Sea, All of the enclosed bays along the coasts of Honshû, 
Shikoku, and Kyûshû, are more or less recognized as a "warm temperate" area. Many of the species found in the Seto Inland Sea have been, therefore, collected by me from other inlets or bays of the Japanese coast, and the occurrences of others are also expected in future. It is a pretty well known fact that many of littoral gammaridean members are generally distributed widely in the world, though they are benthic and normally inhabiting on the muddy sea floor.

Of all the species described here, 59 species (69.4 percent) are found also outside the Japanese area. Their distributional outlines in respective regions are shown in Table 1, and summarized in Figure 44, in which the number of species in each region is shown as the percentage to 59 species. Here, 19 regions are somewhat expediently defined as follows:

I. Arctic region (Baffin Bay, Davis Strait, W. and E. coast of Greenland, Jan Mayen, Murman Coast, White Sea, Barents Sea, Spitsbergen, Bear I., Franz Joseph Land, Novaya Zemlya, Kara Sea, East Siberian Sea, Chukot Sea, and N. coast of Alaska).

II. North-western part of the North Pacific (Bering Sea, Okhotsk Sea, and the Russian coast of the Japan Sea-down to Bay of Peter the Great).

III. Northern part of the Pacific coast of North America (coasts of Alaska and British Columbia).

IV. Southern part of the Pacific coast of North America (coasts of Washington, Oregon, California, and Lower California- to Magdalena Bay southwards).

V. Atlantic coasts of Canada and North America (Gulf of St. Lawrence to New Jersey).

VI. Norwegian coast, including Skagerrak, Kattegat, Baltic Sea, and Iceland.

VII. European coast (down to the coast of Portugal), including Faeroes, Shetland Is., and Azores.

VIII. Mediterranean and its coast, including Black Sea and Sea of Azov.

IX. Northern coast of West Africa (down to the coast of Senegal), including Canary Is. and Cape Verde Is.

X. Tropical coast of West Africa (down to the coast of Cameroon).

XI. Atlantic coast of Central America (coast of Florida, Gulf of Mexico, and Caribbean Sea).

XII. Coasts of Indian Ocean, southwards to $20^{\circ} \mathrm{S}$ (Zanzibar, Amirante Is., Seychelles, Cracados, Suez Canal, Red Sea, Southern Arabian coast, Gulf of Aden, Maladiv Is., Ceylon, Chilka Lake, Tale Sap, and East Indies seas).

XIII. Tropical and subtropical Pacific (Hawaiian Is., Marshall Is., Sulu Sea, Bismarck Arch., Gilbert Is., Fiji Is., N. E. coast of Australia, Kermadec Is., Gambier Arch., and Galapagos Is.).

XIV. Coast of Brazil. 
Table 1. Distributions of the 59 species known also outside the Japanese area in respective regions.

\begin{tabular}{|c|c|c|c|c|c|c|c|c|c|c|c|c|c|c|c|c|c|c|}
\hline & $\mapsto$ & $\boxminus$ & $\Xi 己$ & $>$ & $\vec{p}$ & $\stackrel{5}{5}$ & 占 & 隶 & $x$ & & & & 早 & 学 & $\vec{x}$ & $\vec{x}$ & $\stackrel{3}{3}$ & $\vec{x}$ \\
\hline Socarnes vahli & \# & * & - & - & 年 & $一$ & - & - & - & & - - & - & - & - & - & - & 一 & - \\
\hline Ampithoe lacertosa & $\neq$ & 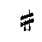 & $-F$ & - & - & - & - & - & - & & - & - & - & - & - & - & $一$ & 一 \\
\hline Leptophoxus falcatus & 专 & - & -- & - & $\#$ & - & - & - & - & & - & - & - & - & - & - & - & - \\
\hline Bathymedon longimanus & * & \# & $-\cdots$ & \# & $\frac{1}{5}$ & - & - & - & - & & - & - & - & - & - & - & - & - \\
\hline Pleustes panopla & $\hbar$ & $=$ & $\pi-$ & \# & $\neq$ & - & - & - & - & & - & - & - & - & - & - & - & $\cdots$ \\
\hline Photis reinhardi & * & 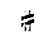 & -- & 来 & \# & 一 & - & - & - & - & - & - & - & - & - & - & - & 一 \\
\hline Podoceropsis nitida & 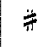 & $\pi$ & $=-$ & $\neq$ & \# & $\neq$ & 一 & - & - & - & - & - & - & - & - & - & - & - \\
\hline Corophium crassicorne & F & F & $\neq-$ & \# & F & $\neq$ & 耘 & - & - & - & - & * & - & - & - & - & - & - \\
\hline Argissa hamatipes & 羊 & 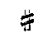 & - $=$ & \# & \# & $\neq$ & - & \# & $\pi$ & & - & 告 & - & - & - & - & - & - \\
\hline Photis longicaudata & F & - & -- & - & $\#$ & 半 & 帮 & 一 & $\neq$ & & 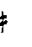 & \# & - & - & - & - & - & - \\
\hline Paraphoxus oculatus & 共 & - & 一节 & - & $\#$ & \# & \# & - & - & & 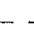 & - & \# & - & 一 & $\pi$ & - & - \\
\hline Corophium acherusicum & 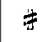 & $-\cdots$ & 守 & - & 一 & $\geqslant$ & 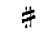 & 击 & F & & 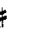 & 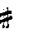 & 丰 & $\Rightarrow$ & - & $\#$ & $\#$ & - \\
\hline Anonyx nugax pacificus & - & $\neq$ & -- & - & - & - & - & - & - & & - & - & - & - & - & - & 一 & - \\
\hline Lepidepecreum vitjazi & - & $\neq$ & -- & - & - & - & - & $-\ldots$ & - & & . & - & - & - & - & - & - & - \\
\hline Aoroides secunda & - & F & -- & - & $\longrightarrow$ & - & - & - & - & & 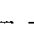 & - & - & - & 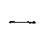 & - & - & - \\
\hline Pontogeneia rostrata & - & 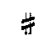 & - 菩 & - & - & - & - & - & - & & L & - & - & - & - & - & - & - \\
\hline Aora typica & - & $\Rightarrow$ & $-\cdots$ & - & $\neq$ & $\neq$ & 若 & * & - & & & . & 来 & 一 & - & 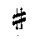 & \# & \# \\
\hline Jassa falcata & - & $\neq$ & 一 & - & $\#$ & $\neq$ & \# & \# & F & & - & 居 & \# & $\#$ & - & 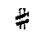 & 韦 & \# \\
\hline Ampithoe valida & - & - & 一击 & $F$ & - & 一 & - & - & - & & - & 一 & - & - & - & - & - & - \\
\hline Corophium volutator & - & - & - & 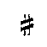 & * & $\%$ & 节 & \# & - & & & & - & - & - & - & - & - \\
\hline Corophium insidiosum & - & - & - \# & \# & - & 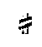 & \# & - & - & & & 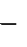 & - & - & - & - & 一 & - \\
\hline Cerapus tubularis & - & - & $-\neq$ & $\#$ & - & - & - & - & - & & & 牛 & \# & - & - & 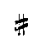 & \# & 一 \\
\hline Aristias pacificus & - & - & $-=$ & - & 一 & - & - & - & - & 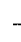 & & - & - & 一 & 一 & - & - & - \\
\hline Gitanopsis vilordes & - & - & $-\approx$ & - & - & 一 & - & - & - & - & & - & - & - & - & - & - & 一 \\
\hline Leucothoe alata & - & - & $-\neq$ & - & - & - & - & - & -- & - & & - & - & - & - & - & - & - \\
\hline Allorchestes angustus & - & 一 & 一寄 & - & - & - & 一 & - & - & . & & & - & - & 一 & - & - & - \\
\hline Aoroides columbiae & - & 一 & 一未 & - & - & - & - & - & - & - & - & - & - & - & - & - & - & - \\
\hline Corophium uenoi & - & - & 一 & - & - & - & - & - & - & 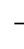 & - & - & 一 & - & - & - & - & - \\
\hline Ampithoe ramondi & - & - & 一 & - & - & F & i & 一 & $E$ & 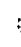 & 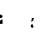 & F & $=$ & - & - & F & - & - \\
\hline Melphidippa borealis & 一 & - & -- & - & $:$ & - & - & - & - & - & . & - & - & - & - & - & - & - \\
\hline Pontocrates altamarinus & - & - & -- & - & 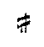 & 丮 & - & - & - & - & - & - & - & - & - & - & - & - \\
\hline Scopelocheirus hopei & - & - & -- & - & $=$ & 尼 & 落 & - & - & 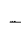 & - & - & - & - & - & 一 & - & - \\
\hline Eriopisa elongata & - & - & - & $\cdots$ & 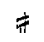 & $\approx$ & \# & - & - & & 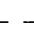 & 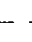 & - & - . & — & - & - & -- \\
\hline Ichnopus taurus & - & - & -- & 一 & $\neq$ & 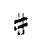 & * & - & - & & 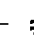 & 聿 & - & - & - & \# &.-- & - \\
\hline Ampelisca brevicornis & - & - & -- & - & 末 & $\Rightarrow$ & \# & 吾 & $\neq$ & & 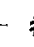 & $\neq$ & 一 & $\rightarrow$ & - & $=$ & - & - \\
\hline Microjassa cumbrensis & - & - & -- & - & - & 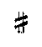 & 一 & - & - & & 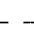 & - & - & - & - . & - & $\longrightarrow$ & - \\
\hline Maerella tenuimana & - & - & -- & - & - & $=$ & 暳 & - & - & & & - & - & - & - & - & - & - \\
\hline Megaluropus agilis & - & - & -- & - & - & $\#$ & 半 & - & - & & & & - & - & - & - & — & - \\
\hline Urothoe pulchella & - & - & -- & - & - & \# & \# & \# & - & & & & - & - & - & - & - & - \\
\hline Hyale schmidti & - & - & -- & - & - & $\#$ & \# & 井 & - & & & & - & 一 & - & 一 & - & - \\
\hline
\end{tabular}


Table 1. (contd.)

\begin{tabular}{|c|c|c|c|c|c|c|c|c|c|c|c|c|c|c|c|c|c|}
\hline & $\mapsto$ & $\boxminus$ & $\Xi Z$ & $>$ & & & 是 & $\not{x}$ & $x$ & $\not \Delta$ & 当 & $\sum_{x}$ & $z$ & $\vec{x}$ & 早 & 当 & $\underset{x}{x}$ \\
\hline Leucothoe incisa & - & - & -- & - & - & $\#$ & $\neq$ & - & \# & - & - & - & - & - & - & - & - \\
\hline Allorchestes plumucornis & - & 一 & -- & - & - & - & $\neq$ & - & - & -- & 一 & - & 一 & - & 一 & - & - \\
\hline Unciolella lunata & - & - & $-\cdots$ & - & - & - & 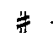 & - & - & -- & - & - & - & - & - & - & - \\
\hline Synopia ultramarina & - & - & -- & - & 一 & 一 & - & $\#$ & 丰 & $-=$ & 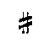 & - & \# & - & - & 一 & - \\
\hline Stenothoe gallensis & - & - & -- & - & - & - & - & - & \# & \#丮 & $\neq$ & - & - & $\approx$ & - & - & - \\
\hline Ampelisca cyclops & - & $\cdots$ & -- & - & - & - & $-\ldots$ & - & - & $-\#$ & - & - & - & - & - & 一 & - \\
\hline Idunella chilkensis & - & - & -- & - & - & - & - & - & - & $-\approx$ & - & - & - & - & - & - & - \\
\hline Eriopisella sechellensis & 一 & - & - & - & 一 & - & - & - & - & $-\#$ & - & - & - & 一 & - & - & - \\
\hline Ampithoe orientalis & - & - & - - & - & - & - & - & - & - & -- & \# & - & 一 & - & - & - & - \\
\hline Ericthonius pugnax & 一 & - & -- & 一 & - & - & - & - & - & 一暳 & \# & - & - & - & \# & - & - \\
\hline Podocerus inconspicuus & - & - & $-\cdots$ & - & - & - & - & - & - & $-\neq$ & - & - & - & $=$ & \# & - & - \\
\hline Ceradocus capensis & - & - & -- & 一 & - & - & - & - & - & $-\cdots$ & - & - & - & \# & - & - & - \\
\hline Endevoura mirabilis & - & - & -- & - & - & - & - & - & - & -- & - & - & - & - & * & - & - \\
\hline Leptamphopus novaezealandiae & - & - & - - & - & - & 一 & - - & - & - & - - & - & - & - & - & 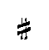 & - & - \\
\hline Paradexamine findersi & - & - & -- & - & & & - & - & - & - & - . & - & - & - & \# & 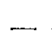 & - \\
\hline Paradexemine barnardi & - & - & $-\cdots$ & - & & . & - & - & - & - & - & - & - & - & $\#$ & - & - \\
\hline Hyale grandicornis & - & - & -- & - & & - & - & - & - & -- & - & - & - & $\#$ & 击 & 邹 & 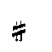 \\
\hline Melita koreana* & - & - - & - - & & & & & & - & & - & -- & 一 & - & - & - & - \\
\hline Anisogammarus annandale $* *$ & - & & - & - & & & & - & - & & - & - & - & - & - & - & - \\
\hline
\end{tabular}

*) Species found also in Makinoshima, Fuzan, Korea, that is not included in any region.

**) Species known also from southern Kuril Is., southern Sakhalin, and China, but all from fresh water localities.

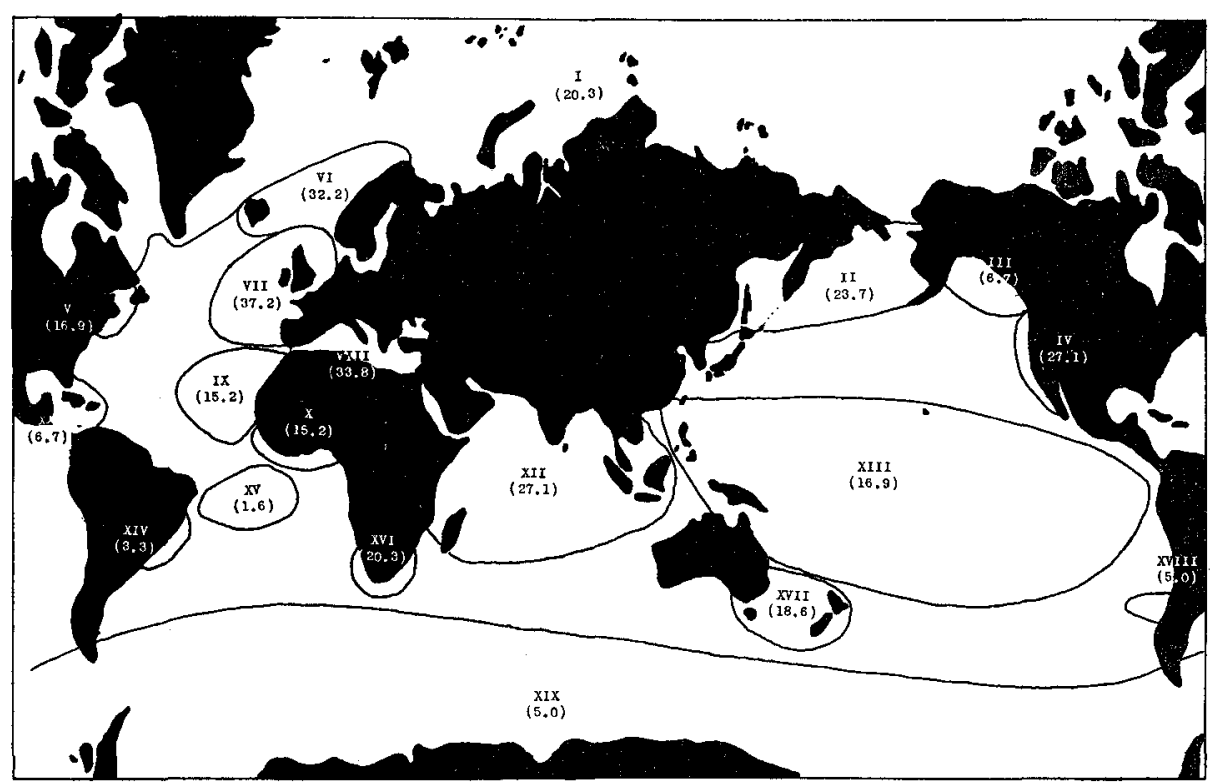

Fig. 44. Number of species in respective regions, represented as percentage to the total 59 species shown on Table 1. 
XV. Tropical Atlantic Ocean (plankton collection).

XVI. Coast of South Africa.

XVII. Coasts of New South Wales and New Zealand, including Auckland Is.

XVIII. Coast of Chile (coast of Valparaiso and Juan Fernandez Is.).

XIX. Antarctic and subantarctic regions (Falkland Is., South Georgia Is., S. Orkney Is., Kerguelen Is., Macquarie Is., and Commonwealth Bay), including Gough Is. of South Atlantic Ocean.

On Table 1, regions are numbered from the north to the south (Regions III and IV may be placed after Region V, but are here inserted just after Region II, as they are fringing all together the North Pacific), and species are generally arranged in the order of northern to southern forms. It will be seen that many of the species have each a wide range of distribution. In fact, their distributions are so variable that it is difficult to divide them into some definite distributional forms; some of them are quite cosmopolitan, some species widely spread in the northern hemisphere, and several may be said, extending over both the eastern and western hemispheres, to be nearly cosmopolitan in boreo-temperate seas, or in temperate to tropical, or also in boreal to tropical. As seen in Figure 44, there are many species common to Japan and the regions far apart from Japan such as Regions V, VI, VII, VIII, XVI, and XVII, and this may be partly attributable to the fact that those regions have been well explored since the early stages of the systematic study for this group.

Most of gammarideans of ten make the nocturnal migration towards the surface water, and therefore they are not necessarily found on the sea bottom, for instance some of them may be found among oyster shells hung from the oyster-raft in the waters more than 10 meters above the bottom, among the drift-algae in the tidal flow or ocean current, or found in colonies on the buoys in harbors. Accordingly, they can be transported to the foreign waters together with oyster spats, or clinging to any ships anchored.

On the other hand, it is very probable that endemic forms are differentiated in such enclosed places as the Inland Sea, affected by the local climate. The following 24 species and 2 subspecies of the forms described in this paper are limited to Japanese waters at present.

Orchomenella littoralis, sp. nov. Ampelisca bocki DAHL

Ampelisca misakiensis DAHL

Ampelisca miharaensis NaGATA

Ampelisca naikaiensis NAGATA

Byblis japonicus DAHL

Harpinia miharaensis NAGATA

Liljeborgia japonica, sp. nov.

Liljeborgia serrata, sp, nov.

Idunella curvidactyla, sp. nov.

Monoculodes limnophilus japonicus, subsp. nov.

Syrrhoites pacificus, sp. nov.

Parapleustes bicuspoides, sp. nov.
Atylus japonicus NaGATA

Melphidippa globosa, sp. nov.

Melphidippella sinuata, sp. nov.

Melphisana japonica, sp. nov.

Melita denticulata, sp. nov.

Melita tuberculata, sp. nov.

Melita japonica, sp. nov.

Maera serratipalma, sp. nov.

Orchestia platensis japonica (TATTERSALL)

Eurystheus japonicus NAGATA

Eurystheus utinomii NAGATA

Corophium kitamorii, sp. nov.

Grandidierella joponica STEPHENSEN

(To be continued) 